\title{
Chapter 2 \\ Globalization and the Emerging State: Past Advance and Future Challenges
}

\author{
Keiichi Tsunekawa
}

\begin{abstract}
This chapter defines and identifies twenty-eight "emerging states" and depicts the general patterns of their economic development and sociopolitical change in relation to institutional and economic globalization. These emerging states have been able to benefit from economic globalization but have avoided being constrained by institutional globalization because they have been able to attract global traders and investors by offering advantages, such as large domestic markets, abundant natural resources, appropriate technological capability, or a combination thereof. In the final analysis, however, upgrading the technological capability of domestic firms and labor and strengthening domestic production linkages will be crucial for the emerging states to further advance economically. They will also need to enhance redistributive measures and reinforce social linkages by narrowing the gap between the globally integrated populations and regions and those that are left behind. Both kinds of linkage strengthening require the close coordination of interests among economic and social forces such as large enterprises, local suppliers, workers, the middle class, and disadvantaged people. This chapter argues that the successful coordination of such interests requires the involvement of public institutions and is deeply affected by firm-government relations, middle-class conservatism, populist mobilization, institutional and ideational legacies from the past, and political leadership for institution- and coalition-building. These topics should be among the priority areas of scholarship for future emerging-state studies.
\end{abstract}

\subsection{Introduction}

Terms such as emerging economy or emerging-market economy have been used mostly in journalism or the business world. As such, they have seldom been subject to scholarly scrutiny. To begin with, the exact meaning of "emerging" has never been clarified. There is only a vague consensus that these economies are highly attractive

K. Tsunekawa $(\bowtie)$

National Graduate Institute for Policy Studies, Tokyo, Japan

e-mail: k-tsunekawa@grips.ac.jp

(C) The Author(s) 2019

T. Shiraishi and T. Sonobe (eds.), Emerging States and Economies, Emerging-Economy

State and International Policy Studies, https://doi.org/10.1007/978-981-13-2634-9_2 
for global traders and investors. Furthermore, as the terms "emerging economy" or "emerging market economy" illustrate, an overwhelming focus has been placed on the economic development of certain countries or regions that are supposed to be "emerging." In practice, economic development is frequently accompanied by sociopolitical transformation, which in turn either fosters or constrains the future trajectory of economic development. Furthermore, rapid economic development of certain countries frequently has serious repercussions for security relations among the nations. For this reason, I use the term emerging "state" instead of emerging "economy" in this chapter. 1

The purpose of this chapter is threefold: first, to define and identify the "emerging state;" second, to clarify the nature of their development in economic, social, and political terms; and third, to explore the kinds of challenges they face as they develop and achieve higher levels of economic and social complexity. As the "emerging" phenomenon most noticeably occurred in the 1990s and 2000s-during which time the pace of the global exchange of goods, money, human talents, and information quickened and global trade increased exponentially-I will examine it by looking closely at its relationship with globalization. The emerging states have been among those most deeply integrated into the global economy and have consequently benefited from and been constrained by globalization.

Identifying emerging states, just like defining "developing countries" or "middleincome countries," is a risky practice because a certain arbitrariness is unavoidable in the selection of categorization standards. However, in the following section, I will venture to introduce certain standards and to identify twenty-eight countries as "emerging states."

Before proceeding, I should clarify what this chapter is not about. It does not attempt any empirical analysis that rigorously tests mutual or causal relationships among various factors. The samples are too selective (they do not contain "nonemerging" states) and the potentially relevant variables (economic, social, political, and institutional) are too diverse to allow me to design a meaningful empirical analysis. This chapter will only try to depict general patterns of economic development and sociopolitical change that have been observed in the selected emerging states.

On the other hand, this chapter is also not a small-N study. It covers as many as twenty-eight countries, and therefore certain details and nuances will have to be compromised. It is not based on original research but relies heavily on secondary materials. The main goal of the chapter is to draw a big picture illustrating the "emerging" phenomenon and indicating directions of future research on the emerging state.

Third, this chapter does not directly deal with impacts of the "emerging" phenomenon on the inter-state relations. The focus of this chapter is the other way around: how and why global factors have affected the "emerging" phenomenon.

\footnotetext{
${ }^{1}$ The entities that are not "independent" national states under the United Nations system will be treated as "emerging states" for the sake of simplicity if their economy operates in a sufficiently autonomous manner (without other countries' intervention).
} 
This chapter is organized in the following manner. In Sect. 2.2, I will present and justify my definition of the emerging state and will select twenty-eight states that fit that definition for the period of 1990-2014. I will also point out that such attempts at defining the emerging state cannot be free from arbitrariness and that the list of the potential emerging states can be expanded by broadening the definition. In addition, Sect. 2.2 will mention that the "emerging" phenomenon is not new but there are historical antecedents during both the pre-WWII and post-WWII periods.

Section 2.3 will explore the existing literature related to the nature of globalization, distinguishing institutional globalization and economic globalization. This section will explore three different positions regarding the economic, social, and political impacts of globalization upon individual national states: optimist, alarmist, and cautious.

In Sect. 2.4, I will examine the extent to which the positive and negative views of globalization are supported by what has actually happened in the last twenty to twenty-five years, specifically by examining the relationship between the extent of globalization on the one hand and economic growth, social improvement, and political transformation (democratization) on the other. This section will demonstrate that the emerging states have been able to gain economic benefits from economic globalization but have avoided being constrained by institutional globalization because they were able to attract global traders and investors by offering certain advantage factors such as large domestic markets, natural resources, and the requisite technological capability, or a combination thereof. However, this section will point out that mere dependence on natural-resource export or domestic market does not guarantee a long-term economic development. As for social and political repercussions of the globalization, Sect. 2.4 will elucidate that no simple pattern is observed.

Section 2.5 will then attempt to explain the divergence of globalization's impacts on the emerging states by focusing on institutional diversities. Since the period of rapid globalization is also regarded as that of political regime changes (to democracy or pseudo-democracy), a special attention will be paid to examining whether such political change is associated with the economic and social performance of the emerging states.

Section 2.6 is concerned with the challenges emerging states face while attempting to realize further economic and social advancement. This section will argue that, in the final analysis, the prospects of emerging states largely depend on the coordination capability of their public institutions. These public institutions must help upgrade the technological capability of domestic firms and the domestic workforce and must strengthen redistributive measures for populations and regions left out of the global integration process, thus broadening and deepening domestic linkages and cohesion. Section 2.6 will then indicate five factors that can affect the coordination capability of public institutions in the emerging states: government-private sector relations, middle-class conservatism, populist mobilization, institutional and ideational legacies from the past, and the nature of the country's political leadership.

In the concluding section, I will argue that the enhancement of domestic linkages is not only an economic or technical matter but is also deeply connected to political factors. The reason is that pro-linkage endeavors require complex coordination 
among many groups across the social spectrum. This section will also point out that the five factors that can affect such coordination in the emerging states should simultaneously be among the priority areas of scholarship for future emerging-state studies.

\subsection{Which Countries Are the Emerging States?}

The attempt to categorize countries (economies) into specific groups is always accompanied by arbitrariness with regard to the standards used for such categorization. The selection of emerging states is no exception. The BRICs and G20 groupings are too narrow to cover many other important countries in the world. I contend that there are two basic reasons why emerging states have attracted broad attention in the contemporary world. These reasons should be taken into account in the identification of emerging states. First, they were "developing" countries before the 1980s but are now regarded as "emerging" because their speed of economic catch-up with the "advanced" industrial countries is noticeably high. Second, as their share in the global economy has expanded, they are regarded as the partners (no longer the followers or beneficiaries) of "advanced" countries that must share certain responsibilities in the effective governance of various aspects of the global economy. For these two reasons, I use GDP per capita and the size and growth rate of GDP (relative to those of the "advanced" countries) as the standards for identifying emerging states.

First, since the emerging states were "developing countries" before the 1980s, the countries whose per capita GDP in 1990 was greater than that of Singapore (which was the forerunner among the contemporary developing countries and had attained "high-income country" status in the early 1980s) must be excluded. ${ }^{2}$

Second, for a country to be called "emerging," it must have achieved a GDP growth rate greater than the growth rate of "advanced" countries for the 1990-2014 period. Here, I use the US growth rate (78.2\% increase between 1990 and 2014) as the benchmark.

Third, the size of the country's economy (which is a proxy of its relative importance in the world) is considered. It is here that the greatest arbitrariness occurs, but I temporarily set $1.0 \%$ of the US GDP in 2014 as the standard by which I selected the emerging states.

This exercise leaves twenty-seven countries (economies). I have added Russia to this list, even though its growth rate for the period 1990-2014 (18.7\%) was substantially lower than the US growth rate for this period. We need to consider the exceptionally steep decline of the Russian economy in the 1990s due to the breakdown of the Soviet Union. It shrunk by $25.9 \%$ between 1990 and 2002. If the growth rate is calculated only for 2003-2015, Russia recorded 60.3\% vis-à-vis US's 23.8\%. Moreover, the Russian economy - the size of which was $10.4 \%$ of US GDP in 2014-is still the fourth largest among the emerging states and is too large to be excluded.

\footnotetext{
${ }^{2}$ Singapore's per capita GDP in 1990 was $\$ 11,865$ (in current USD).
} 
Table 2.1 Emerging states by region and income level

\begin{tabular}{|c|c|c|c|}
\hline & High income & Upper middle income & Lower middle income \\
\hline East and South Asia & $\begin{array}{l}\text { Singapore } \\
\text { South Korea } \\
\text { Taiwan }\end{array}$ & $\begin{array}{l}\text { Malaysia } \\
\text { China } \\
\text { Thailand }\end{array}$ & $\begin{array}{l}\text { Indonesia } \\
\text { Philippines } \\
\text { India } \\
\text { Pakistan }\end{array}$ \\
\hline Latin America & Chile & $\begin{array}{l}\text { Brazil } \\
\text { Argentina } \\
\text { Mexico } \\
\text { Venezuela } \\
\text { Colombia } \\
\text { Peru }\end{array}$ & \\
\hline $\begin{array}{l}\text { Former USSR and } \\
\text { Eastern Europe }\end{array}$ & $\begin{array}{l}\text { Poland } \\
\text { Russia }\end{array}$ & Kazakhstan & \\
\hline $\begin{array}{l}\text { Middle East and } \\
\text { North Africa }\end{array}$ & Saudi Arabia & $\begin{array}{l}\text { Turkey } \\
\text { Iran } \\
\text { Iraq } \\
\text { Algeria }\end{array}$ & Egypt \\
\hline Sub-Sahara Africa & & South Africa & Nigeria \\
\hline
\end{tabular}

Note Countries in thick letters are G20 members. Source Appendix 1

On the other hand, Vietnam and Bangladesh are excluded, although their growth rates were more than triple that of the United States during the period of 1990-2014. This exclusion is because their GDPs had not yet reached the $1.0 \%$ benchmark by 2014. They will certainly reach that threshold before long. The list of next-generation emerging states (including Vietnam, Bangladesh, Ethiopia, Uganda, and Ghana) is long, ${ }^{3}$ but most of them are small countries whose relations with the global economy and their mode of growth seem to be quite different from the mostly upper-middle or high-income countries that I chose as emerging states. I will return to this subject in the next section.

Consequently, as of 2014, there are twenty-eight countries or economies that form the group of "emerging states" (Table 2.1). Regionally, Asia (both East and South) contains the greatest number of emerging states, followed by Latin America and MENA (Middle East and North Africa). Fifteen out of twenty-eight countries belong to the higher-middle-income category defined by the World Bank. ${ }^{4}$ Seven are categorized as high-income economies and six as lower-middle-income countries. The list covers all eleven G20 members that were not "advanced" countries before the mid-1980s.

Although this chapter focuses on the contemporary emerging states, it is worth mentioning that there are historical antecedents for them. Fig. 2.1 shows the size

\footnotetext{
${ }^{3}$ The countries whose growth rate was more than double the US rate between 1990 and 2014 number as many as thirty-nine without counting the current emerging states.

${ }^{4}$ As for standards set by the World Bank to classify income groups in different years, refer to http://databank.worldbank.org/data/download/site-content/OGHIST.xls (accessed on September $18,2016)$.
} 


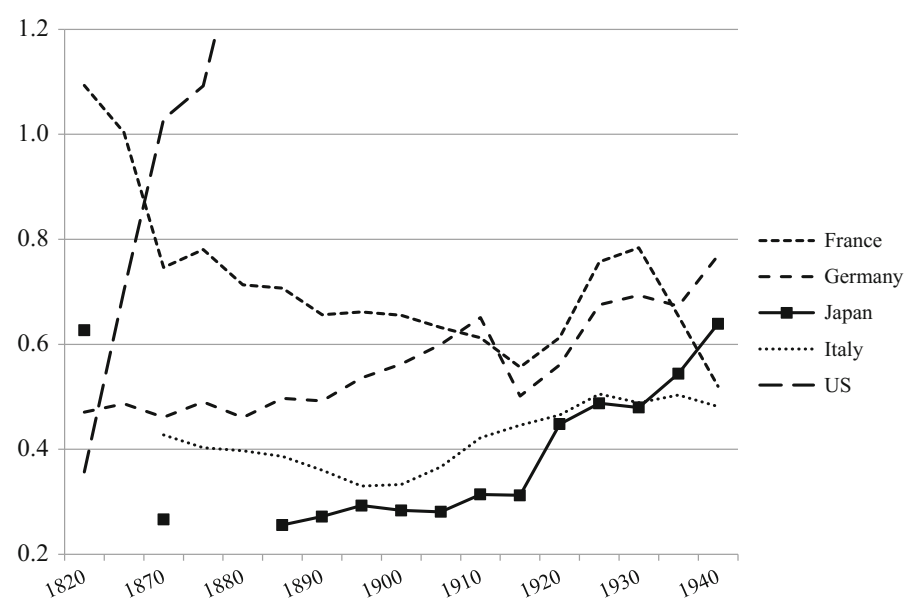

Fig. 2.1 Relative size of GDP(United Kingdom = 1.0). Source Own calculation based on Maddison (1995, Table C-16)

of GDP of several major countries relative to that of the United Kingdom for the period covering 1820-1940. The US economy surpassed the UK's by 1870 while France declined over a century vis-à-vis the United Kingdom. The growth trajectory of Germany, Italy, and Japan demonstrates a long-term catching-up with the United Kingdom although the starting years are different for the three. These three countries and the United States are clear historical cases of the emerging states. However, a similar pattern is not observed when the United States is used as the benchmark country. Figure 2.2 shows that Soviet Union, France, Germany, Italy, and Japan experienced the narrowing of economic gap with the United States before the WWII, but such experience lasted only for ten to twenty years. After a sharp economic decline during the war, these countries restarted the catching up. However, except for Japan, they could never advance beyond the prewar peak. In that sense, Japan was the only clear case of the emerging state vis-à-vis the United States.

The developing countries/economies have a better performance in the postwar period in terms of the catching-up with the United States. Many of the twenty-eight emerging states listed in Table 2.1 started their catching-up process much earlier than 1990. Among twenty-six countries for which data for earlier periods are available, twenty (mostly from Asia, Middle East, and North Africa) recorded economic growth greater than the United States in 1960-1990. ${ }^{5}$ What happened after 1990 is the spread of the "emerging" phenomenon to cover the whole developing areas.

\footnotetext{
${ }^{5}$ This observation results from the author's calculation based on the GDP data from World Bank's World Development Indicators database and Maddison (1995, Table C-16).
} 


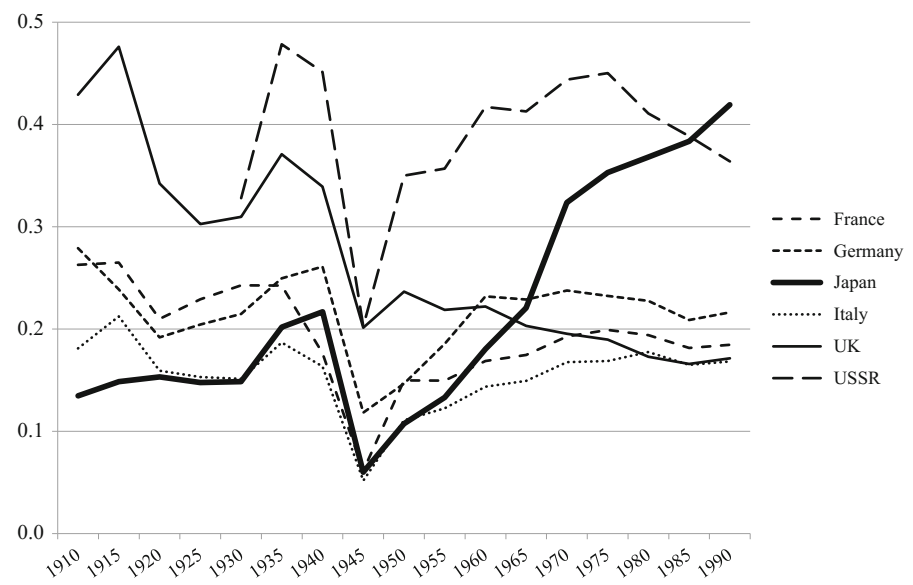

Fig. 2.2 Relative size of GDP (United States =1.0). Source Own calculation based on Maddison (1995, Table C-16)

\subsection{Globalization and Its Anticipated Impacts on the Emerging States}

\subsubsection{Anticipated Impacts of Globalization}

As the world-wise spread of the "emerging" phenomenon occurred in the 1990s and 2000s in which the speed of globalization quickened, it will be legitimate to inquire of impacts of globalization on the emerging states. In practice, globalization has been one of the most popular topics in both the scholarly and business circles during the last twenty to thirty years.

There are three different views — optimistic, alarmist, and cautious — on how globalization has affected national states including the emerging states. The optimistic view, which is especially popular among business people, regards globalization as highly beneficial to any country in the world. Kenichi Ohmae's books $(1990,1996)$ fully embody this view. He argues that the intensified competition over markets (for both final and intermediate goods) has forced firms to search for business partners beyond borders to reduce fixed costs. Economic activities have become borderless and as a consequence national states are no longer the main actors when it comes to protecting people's well-being. Interventions by national states generally interfere with efficient production and distribution by global economic actors and serve to reduce overall welfare.

In contrast to the first view, the second view is rather pessimistic in its evaluation of globalization. This view does not deny that globalization has brought certain benefits to individual national states. However, it is highly concerned about globalization's 
negative impact on the policymaking autonomy of individual national states regarding economic and social matters. This concern was strongly expressed by Susan Strange:

[The] impersonal forces of world markets, integrated over the postwar period more by private enterprise in finance, industry and trade than by the cooperative decisions of governments, are now more powerful than the states to whom ultimate political authority over society and economy is supposed to belong. (Strange 1996, p. 4)

She argues that decisions about production, trade, investment, and finance are increasingly controlled by multinational corporations (MNCs) and their global networks. Consequently, the authority of national governments is heavily constrained in many policy fields including national currency, development strategy, economic cycles, social welfare, tax, trade, and labor. As a result, damages are incurred, especially against the interests of workers, citizens, and small-sized firms. If a national government attempts to strengthen laws and regulations governing MNCs, they will simply transfer their activities to some other country with a weaker regulatory regime (Strange 1996, Chaps. 4 and 5).

Concerns about the adverse effects of globalization on national policymaking autonomy are shared by Dani Rodrik in his early work (1997). Echoing Polanyi's argument about the "double movements" (Polanyi 2001 [1944]), Rodrik warns that the national government's capacity to provide social insurance is being curtailed by the increasing mobility of capital, because such mobility has left a large portion of the tax base unmoored. As social insurance has been "one of their [governments'] central functions and one that has helped maintain social cohesion and domestic political support for ongoing liberalization," the shrinkage of that function will lead to the enhancement of anti-globalization voices (Rodrik 1997, p. 6, pp. 70-71).

Thomas Friedman, a journalist for the New York Times, also believes that space for policy choices by national governments has been narrowed by globalization. The global economy functions as a "golden straitjacket" for which only one size is available. A national government that fails to fit itself into that size will see investors leave its country and its economy fall into stagnation (Friedman 1999/2000, pp. 103-4). He warns that the people who seek trust and security from traditional identities (such as family, community, and nation) rather than from the global economy may revolt against global economic forces unless an adequate social safety net is made available (Friedman 1999/2000, p. 41, pp. 424-25).

In addition to the social effects of globalization, Rodrik mentions its political effects. Rodrik expresses his preference for democracy as a political institution that can process and aggregate local knowledge and needs in order to realize economic growth that is inclusive, resilient, and secure over the long term (Rodrik 2007, Chap. 5). However, he believes that there is a contradiction between democracy and globalization. Actually, he writes about a "political trilemma of the world economy," arguing that a country can have only two of the following three: "hyperglobalization," "democratic politics," and the "nation state" (Rodrik 2011, Chap. 9). In practice, the option of not having the national state is unavailable because, as Rodrik himself admits, a strong global governance regime supported by equally strong global democratic societies is too unrealistic. I would argue that the dilemma 
between democracy and globalization, rather than a trilemma, is the real problem. To solve this dilemma, Rodrik proposes moderating the application of global rules (that is institutional globalization) (Rodrik 2011, Chap. 12). This reasoning leads us to question whether democracy must be compromised if institutional globalization cannot be scaled down.

The third view on the impact of globalization shares with the second view a concern about its negative effects but differs in its admission that the constraints of globalization are not as strong as suggested by the second view. This third view leaves enough room for policy and institutional choice, at least for certain countries. It recognizes differentiated impacts of globalization for different countries.

For instance, Mosley (2003) investigated the relationship between global investors' behavior and the degree of national policy autonomy through quantitative analyses of government bond rates and interviews with sixty-four executives of major financial firms and rating companies. Mosley concluded that the executives of these international companies only consider key macroeconomic indicators such as inflation and budget deficit levels when making their investment decisions in "advanced" capitalist countries. Consequently, national governments in these countries can have a certain amount of autonomy to satisfy domestic necessities in the fields of taxation, labor-market regulation, and social welfare. However, emerging market governments face greater constraints because investors take into consideration many dimensions of government policy when they make asset allocation decisions. In the same line of argument, Wibbels (2006, p. 462) points out that the fiscal policy of developing countries tends to be procyclical (not countercyclical) because their access to international credit markets is limited during economic downturns. ${ }^{6}$ Mosley, however, observes that international investors' behavior in different emerging market countries is not monolithic. It diverges depending upon their evaluation of the credit risks of different regions and countries (Mosley 2003, Chap. 4).

During their discussion of global constraints (or the lack thereof) upon national political regimes, Acemoglu and Robinson distance themselves from Rodrik's view of democracy-globalization dilemma and admit the theoretical possibility that globalization fosters democracy because the expansion of global trade in poor countries "should reduce the income gap between the poor who earn their living from labor and the rich who are the capital holders" (2006, p. 322). This income gap reduction will moderate the behavior of the rich and the poor to the extent that peaceful coexistence becomes possible. They also infer that the increase in capital mobility makes democracy less threatening (and therefore more acceptable) to elites because they can expect that governments, fearing capital flight, will avoid heavy capital controls even under local democratic pressure to move in that direction. Acemoglu and Robinson (2006, Chap. 10), however, call for caution, observing that the relationship between global trade/investment and democracy has not yet been conclusively established. It depends on many factors, including the relative abundance of production factors, initial income distribution, and the distributional impacts of capital mobility.

\footnotetext{
${ }^{6}$ Kaplan (2013) makes a similar argument about countries in Latin America.
} 
Differing from the work of Mosley and that of Acemoglu and Robinson, who view the impact of globalization from the perspective of global opportunities (or constraints), many authors emphasize the importance of national political and institutional arrangements to explain the differing performances of national states that compete under similar global constraints. For instance, in his 2007 publication (originally written in 2005), Dani Rodrik provides a view that is less pessimistic than that of his other works. He argues that there can be "many recipes" in "one economics." If developing countries build appropriate institutions that respond to their national needs and conditions, they will be able to skirt global constraints and utilize the global economy for their own benefits.

Searching for national institutions suitable for economic development, Doner and his associates, who are concerned about the economic slowdown (that came to be known as the "middle-income trap" after 2007), emphasize the importance of institutions that foster the technological advancement of national firms and the labor force, thereby helping a country move up in the global production networks (Doner and Ramsay 2003; Doner et al. 2005; Doner 2009, 2015; Doner and Schneider 2016). For these authors, strengthening domestic linkages through interest coordination is essential. Workers and managers must cooperate on the shop floor to improve productivity and process technologies. Upstream firms and downstream firms must coordinate the scale, scope, and timing of investment and production. They may also need to compromise concerning the reduction of import tariffs at different stages of the production chain. Furthermore, to increase the amount of highly skilled human capital available, government budgets for higher education and technical training must be increased. Research and development $(\mathrm{R} \& \mathrm{D})$ budgets also need to be expanded. However, to increase these budgets, the government must either raise taxes or reduce other expenditures. Somebody needs to shoulder the burden. In this sense, as Doner and Schneider (2016) properly observed, technological upgrading is a highly political endeavor.

\subsubsection{Two Aspects of Globalization and the Emerging States}

So far, we have treated globalization as a single unified process. However, to understand the nature of impacts of globalization on the emerging states, it is important to distinguish two different aspects of globalization: institutional and economic. Institutional globalization is the spread of global standards and rules mostly set by intergovernmental negotiations led by the advanced countries. The rules set by the WTO concerning trade and intellectual property rights are typical expressions of institutional globalization. Market-oriented reforms required by the IMF and other global actors in exchange for financial support are another example of institutional globalization.

Economic globalization is the expansion of global transactions. As many studies of the global production network (GPN) point out, this process of economic globalization is mostly based on the economic activities of private firms and has been 
fostered by the spread of complex networks of firms beyond borders, especially since the 1990s.

The development of scholarly studies of the GPN has been well-documented in Coe and Yeung's comprehensive work (Coe and Yeung 2015). The source of GPN development is the fragmentation (vertical disintegration) of the production process and the transfer of a part of the process (assembly and/or parts production) abroad from the "advanced" industrial countries. Helped by the increasing modularization of parts and components and by the further development of information and transportation technologies, leading firms of the "advanced" countries shifted larger segments of their operations to locations where they could have greater global competitiveness in terms of market access, production costs, and the availability of technology. The leading firms increasingly specialized in those segments in which they possessed the greatest core competences, such as product development, the production of core products, brand management, and global marketing. This specialization left a large portion of manufacturing activities and business support services within the host countries.

Foreign direct investment (FDI) plays an important role in the formation of the GPN. However, according to Coe and Yeung (2015) and Yeung (2016), the GPN does not necessarily need subsidiaries of the leading firms to be established in the host countries, because, as the technological capability of local firms and workers improves, partnership without ownership (including outsourcing, contract manufacturing, and licensing arrangement) has increased between the leading global firms and local firms. In some cases, this partnership has reached the stage in which not only production but also product design and development are entrusted to the emerging partners.

The two aspects of globalization mentioned above are anticipated to affect the emerging states differently from how they affect the "advanced" countries and the less developed ones.

Institutional globalization demands more from the emerging states than the less developed countries because the emerging states grow and catch up quickly with the "advanced" countries, causing frequent trade disputes. The advanced countries and international organizations demand stricter application of the global trade rules from the emerging states, including tariff reductions, implementation of intellectual property rights, equal treatment of domestic and foreign firms, and the reduction of non-trade barriers.

The emerging states also tend to be subject to greater disciplinary pressure from the IMF and other global actors because the creditworthiness of their public and private sectors attracts a large amount of foreign financial capital while their economies are still vulnerable to sudden shocks. As shown by the Latin American debt crisis in the 1980s and the Asian financial crisis (AFC) in the 1990s, once large amounts of foreign funding start to exit or cease to come in, the indebted countries are forced to adopt free market-oriented policies such as fiscal balance, reduction of subsidies, market-based adjustment of domestic prices and exchange rates, and privatization (Teichman 2001, Chap. 3). 
Many less developed countries have also fallen into national bankruptcy. However, due to the small size of their economies, the global impact of their crises are minimal and consequently draw little international attention except on the issue of destitution. As far as the less developed countries are concerned, since the late 1990s policies demanded by the international organizations have focused more on poverty reduction than on market-oriented reforms (World Bank 2000).

The "advanced" countries are not free from trade disputes or financial crises, as shown by the Japan-United States trade friction in the 1980s and 1990s, the Lehman Brothers shock, and the European debt crisis in the 2000s. However, the constraints imposed by institutional globalization are weaker for them because "advanced" countries generally started institutional liberalization much earlier than the emerging states and attained high levels of liberalization by the 1990s. Their requests for the IMF's help are also less frequent.

With regard to economic globalization, the emerging states are deeply involved in the GPNs, a contemporary incarnation of economic globalization. Some of them started to build their manufacturing might by accepting FDI and/or participating in outsourcing networks and have since deepened their integration into the GPNs as they have moved up the global value chain to the middle or higher value-added sectors. In the process, some of them are supposedly susceptible to the "middle-income trap." A country (or economy) falls into this trap when, after having experienced years of high growth, long-term stagnation or decline sets in. Such a situation emerges when middle-income countries are "squeezed between the low-wage poor-country competitors that dominate in mature industries and the rich-country innovators that dominate in industries undergoing rapid technological change" (Gill and Kharas 2007, p. 5) due to the difficulty in moving up in the GPNs in terms of technological capacity (as for the middle-income trap, c.f. Yusuf and Nabeshima 2009; Doner 2009; Ohno 2009; Kohli et al. 2011; Felipe et al. 2012; Aaron et al. 2013; Gill and Kharas 2015).

The less developed countries and the "advanced" countries are also involved in economic globalization. The former, however, are integrated into lower value-added segments of the GPNs as labor-intensive manufactures or natural-resource exporters. The advanced capitalist countries are hosts for many global lead firms that compete for technological breakthrough.

In short, the emerging states are in the middle ground, being subject to strong pressures for institutional globalization and for specific adjustment for economic globalization.

\subsection{Actual Impacts of Globalization on the Emerging States}

The purpose of this section is to determine whether the impacts anticipated by the previous literature are congruent with what has actually happened in the emerging states. As I pointed out in the first section, my purpose is not to map exact correlations 
between globalization and economic, social, and political transformation but rather to observe general patterns across many emerging states.

\subsubsection{Globalization and Economic Growth}

The fact that the emerging states have been rapidly catching up with the "advanced" countries signifies that their economic growth has not been blocked by globalization. However, a closer examination is necessary to determine the extent to which globalization has been associated with a high level of economic performance of emerging states.

This is where globalization is divided into institutional globalization and economic globalization. To measure the degree to which each emerging state is exposed to institutional globalization (i.e., actual compliance with global rules of economic transaction), I use the Economic Freedom Score provided by the Heritage Foundation because, unlike other similar indicators (which attempt to measure broad business environments), this indicator is constructed using only indices that measure market freedom, such as property rights, trade and investment openness, fiscal balance, and labor market flexibility. On the other hand, I will measure economic globalization using two indicators: the ratio of trade to GDP and the ratio of inward FDI to GDP. All measures are calculated for the twelve-year period from 2003 to 2014 (see Appendix 2).

Clearly, Singapore is an exceptional case. Its trade and FDI ratios to GDP are abnormally high and could distort the whole analysis. For instance, the correlation coefficient between the trade ratio and the FDI ratio is very high $\left(\mathrm{R}^{2}=0.80\right)$ if Singapore is included, but it goes down sharply (to 0.09) if Singapore is excluded. Hence, Singapore has been excluded from this analysis. The main findings are as follows:

(1) A higher level of institutional globalization is not associated with increased economic growth. In fact, Fig. 2.3 indicates a reverse correlation between the two. A closer look at the scattergram, however, reveals that three countries-China, India, and Nigeria - that have attained exceptionally high growth rates despite low levels of institutional globalization have strongly contributed to the reverse correlation. If these three countries are excluded as deviant cases, no correlation is found concerning the level of institutional globalization and economic growth. Global rules enforced by the WTO and other arrangements neither improve nor constrain the economic performance of the emerging states.

(2) At first glance, economic globalization does not seem to be associated with the growth rate. The scattergrams that show relationships between the trade ratio and GDP growth (Fig. 2.4) and between the FDI ratio and GDP growth (Fig. 2.5) demonstrate that no clear-cut relationship exists in each pair. Again, China, India, and Nigeria are the main deviant cases. Their trade ratios and FDI ratios (to GDP) are quite low, but their growth rates are among the highest of the emerging 
GDP Growth Rate (\%)

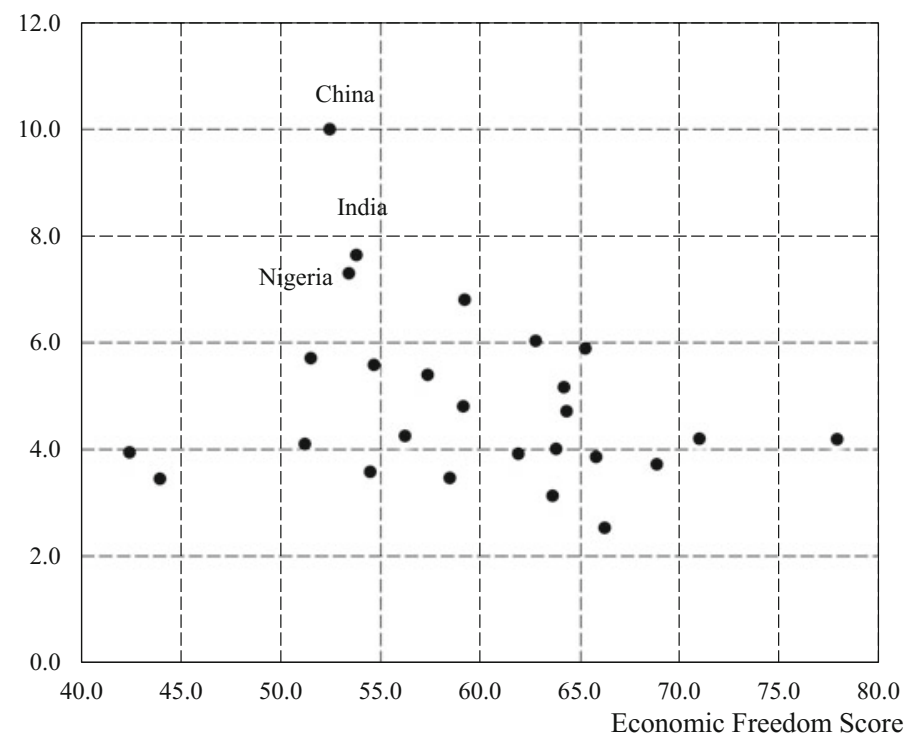

Fig. 2.3 Institutional globalization and growth rates 2003-14 (annual average). Source Appendix 2

states. However, as far as China and India are concerned, this contradiction is superficial to a certain extent. China and India are large countries in economic, geographic, and demographic terms. If the ratio to GDP is calculated, the result should be small simply because the denominator is large, falsely suggesting that their global connections are few. In practice, most of the leading economic sectors in these countries are concentrated in certain geographical areas (such as the coastal regions of China); if this geographical bias is taken into account, China's and India's position in Figs. 2.4 and 2.5 will move in the right-hand direction, strengthening the correlations between the trade ratio and FDI ratio on the one hand and the economic growth rate on the other. Furthermore, calculating China's and India's shares in the total amount of global trade and FDI for the period ranging from 2003 to 2014 reveals that China was at the top in both measures while India was ranked third for trade and sixth for FDI (refer to Appendix 2). It is clear that China and India, in spite of their low levels of institutional globalization, attracted many global traders and investors through whom these countries have strongly participated in and benefited from economic globalization. Nigeria is left as an unexplained case. One possible reason for the exceptionally good economic performance of Nigeria in recent years is that it recovered stability in 1999 after many years of political instability and economic volatility and began a speedy economic recovery based on the rising international price of petroleum. 
GDP Growth Rate (\%)

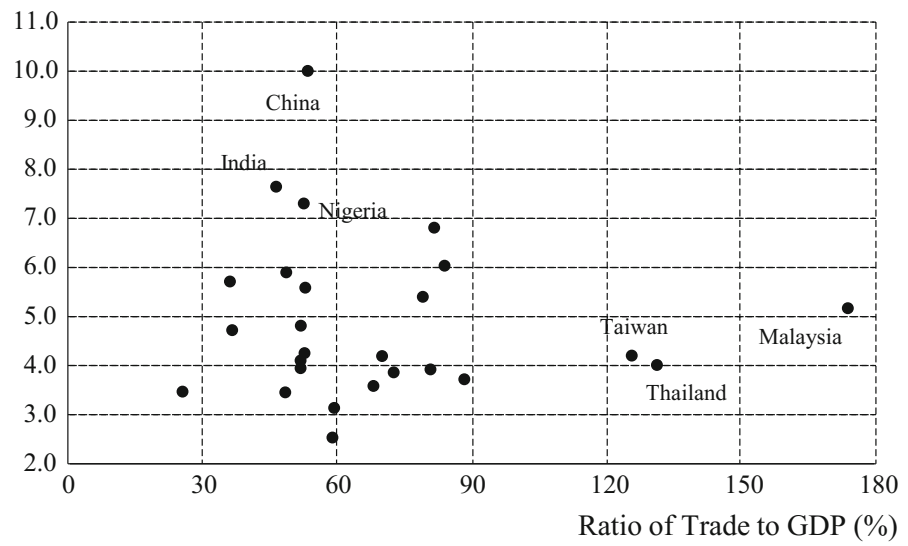

Fig. 2.4 Ratio of trade to GDP and growth rates 2003-14 (annual average). Source Appendix 2

GDP Growth Rate (\%)

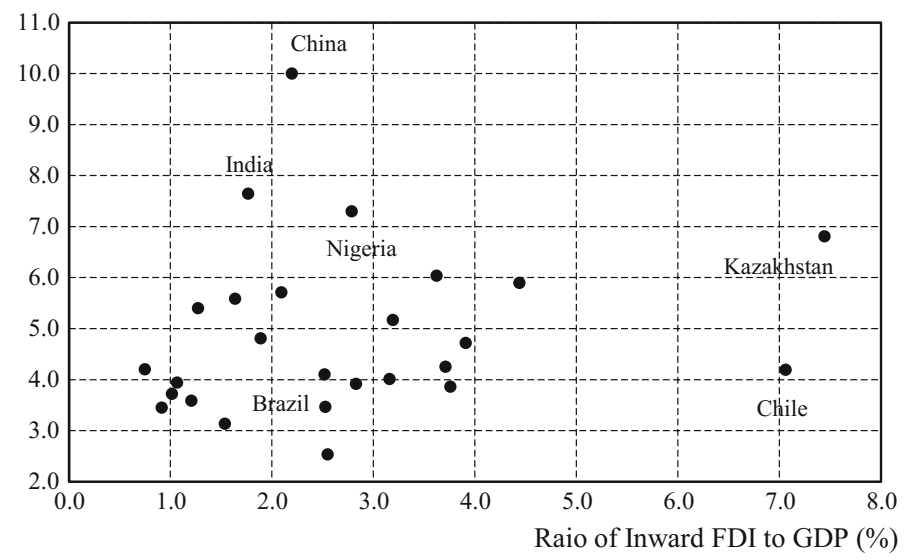

Fig. 2.5 Ratio of inward FDI and growth rates 2003-14 (annual average). Source Appendix 2

(3) The above discussion indicates that there are advantage factors that attract global investors regardless of the extent of an emerging state's institutional globalization. First, the cases of China and India point to the importance of the size of a country's domestic market. Second, the Nigerian case may be indicative of the importance of natural resource endowment. The fact that more than one third of the twenty-eight emerging states depend on natural resources for more than $60 \%$ of their total exports supports this contention. Third, Fig. 2.4 clearly indicates that countries (such as Malaysia, Thailand, and Taiwan) with neither large domestic markets nor high levels of natural resource endowment are highly dependent upon trade. Since a great majority of their exports are manufactured 
goods, it is crucial for these countries to upgrade their technological capability in order to move up in the GPNs and be able to continuously benefit from economic globalization.

Table 2.2 shows how the three advantage factors-domestic market size, natural resources for export, and technological capability-are distributed among the emerging states. Domestic market size is measured by GDP as a percent of US GDP in 2014 (adopted from Appendix 1). Natural resources for export (including fuel, mineral, and agricultural) are measured by their share of total exports in 2006, when the international price of natural resources was rapidly increasing. Technological capability is measured by the net export ratio (NER) of capital goods and parts and components. ${ }^{7}$ Capital goods and parts and components are assumed to be the most complex and technologically sophisticated merchandise. Table 2.2 shows NERs in 2014 and the improvement of NERs between 1995 and 2014.

The emerging states are classified into three groups. The first group is composed of resource-rich countries while the second group covers large-market countries. Russia is included in both. The third group consists of the countries whose domestic market is relatively small and whose share of natural resource exports are not as high as that of the first group of countries. We can discern several interesting patterns in Table 2.2.

(1) The countries that depend heavily on exporting natural resources have small domestic markets except for Russia (and Saudi Arabia to a lesser extent). Their economy is highly vulnerable to the fluctuation of international price of natural resources. The last column of Table 2.2 shows that most of the emerging states experienced declines of GDP growth rate after 2009 when the global recession spread to the whole world but the decline in the resource-dependent countries was especially steep. The record of their NERs is also poor. Although we lack information on the NERs (of capital goods and of parts and components) of many of these countries, we can reasonably assume that their NER is close to zero because their level of manufactured exports is very low. The countries for which we have NER information (Russia, Chile, Peru, and Egypt) experienced either a decline or only minimal improvement of NERs between 1995 and 2014, and their NERs in 2014 were still close to the bottom $(-1.0)$. Natural resource dependence may have a self-reinforcing effect in the sense that resource-dependent countries continue to depend on exporting resources for a long time. The poor performance of Chile may look odd as it is regarded as economically the most successful case in Latin America and is the only country in its region that has attained the status of a high-income country by World Bank standards. The point made by Caldentey (2012) on this matter is illuminating. According to his analysis, Chile has succeeded in developing several "pockets of excellence" in the processing

\footnotetext{
${ }^{7}$ The net export ratio is calculated by dividing the trade surplus of merchandise or a merchandise category by the sum of exports and imports of the same merchandise or merchandise category. It is a rough indicator of the international competitiveness of the merchandise or merchandise category of a certain country.
} 
Table 2.2 Advantage factors of the emerging states

\begin{tabular}{|c|c|c|c|c|c|c|}
\hline & \multirow{2}{*}{$\begin{array}{l}\text { Market } \\
\text { size (GDP } \\
\text { as \% of US } \\
\text { GDP in } \\
2014 \text { ) }\end{array}$} & \multirow{2}{*}{$\begin{array}{l}\text { Natural } \\
\text { resource } \\
\text { export } \\
\text { (share of } \\
\text { total mer- } \\
\text { chandise } \\
\text { export in } \\
2006 \text { ) }\end{array}$} & \multicolumn{2}{|l|}{$\begin{array}{l}\text { Technological } \\
\text { capability }\end{array}$} & \multicolumn{2}{|c|}{ GDP growth rate } \\
\hline & & & $\begin{array}{l}\text { Net export } \\
\text { ratio of } \\
\text { complex } \\
\text { manufactured } \\
\text { goods in } 2014\end{array}$ & \begin{tabular}{|l} 
Improvement \\
of net \\
export ratio \\
between \\
1995 and \\
2014
\end{tabular} & $\begin{array}{l}\text { Annual } \\
\text { average for } \\
\text { 2003-2014 }\end{array}$ & $\begin{array}{l}\text { Percentage } \\
\text { points } \\
\text { difference } \\
\text { between } \\
2003-08 \\
\text { and } \\
2009-14\end{array}$ \\
\hline \multicolumn{7}{|c|}{ Resource-dependent countries } \\
\hline Iraq & 1.1 & 99.6 & Close to -1.0 & Close to 0.0 & 6.7 & -1.6 \\
\hline Algeria & 1.1 & 98.6 & Close to -1.0 & Close to 0.0 & 3.6 & -1.1 \\
\hline Nigeria & 2.8 & 98.6 & Close to -1.0 & Close to 0.0 & 7.3 & -5.5 \\
\hline Venezuela & 2.6 & 94.4 & Close to -1.0 & Close to 0.0 & 3.9 & -7.0 \\
\hline $\begin{array}{l}\text { Saudi } \\
\text { Arabia }\end{array}$ & 4.0 & 91.3 & Close to -1.0 & Close to 0.0 & 6.0 & -2.7 \\
\hline Iran & 2.9 & 85.6 & Close to -1.0 & Close to 0.0 & 3.4 & -4.1 \\
\hline Kazakhstan & 1.1 & 84.7 & Close to -1.0 & Close to 0.0 & 6.8 & -3.5 \\
\hline Russia & 10.4 & 73.7 & -0.8 & -0.24 & 4.1 & -6.1 \\
\hline Chile & 1.6 & 71.5 & -0.88 & 0.04 & 4.2 & -1.1 \\
\hline Peru & 1.1 & 68.3 & -0.92 & 0.05 & 5.9 & -1.7 \\
\hline Egypt & 1.5 & 60.2 & -0.9 & -3.2 & 4.3 & -2.4 \\
\hline \multicolumn{7}{|c|}{ Large-market countries } \\
\hline China & 50.9 & 4.5 & 0.32 & 0.39 & 10.0 & -2.7 \\
\hline Brazil & 14.9 & 22.2 & -0.47 & -0.09 & 3.5 & -1.5 \\
\hline India & 13.6 & 24.1 & -0.38 & 0.15 & 7.6 & -0.3 \\
\hline Russia & 10.4 & 73.7 & -0.8 & -0.24 & 4.1 & -6.1 \\
\hline $\begin{array}{l}\text { South } \\
\text { Korea }\end{array}$ & 7.6 & 9.6 & 0.35 & 0.39 & 3.7 & -1.0 \\
\hline Mexico & 7.3 & 18.3 & 0.00 & 0.00 & 2.5 & -1.0 \\
\hline \multicolumn{7}{|c|}{ Other countries } \\
\hline Philippines & 1.6 & 7.3 & 0.31 & 0.30 & 5.4 & 0.0 \\
\hline Taiwan & 3.1 & n.a. & 0.30 & 0.15 & 4.2 & -0.7 \\
\hline Malaysia & 1.9 & 17.9 & 0.20 & 0.24 & 5.2 & -1.2 \\
\hline Thailand & 2.4 & 11.5 & 0.10 & 0.37 & 4.0 & -1.9 \\
\hline
\end{tabular}


Table 2.2 (continued)

\begin{tabular}{|c|c|c|c|c|c|c|}
\hline & \multirow{2}{*}{$\begin{array}{l}\text { Market } \\
\text { size (GDP } \\
\text { as \% of US } \\
\text { GDP in } \\
2014)\end{array}$} & \multirow{2}{*}{$\begin{array}{l}\text { Natural } \\
\text { resource } \\
\text { export } \\
\text { (share of } \\
\text { total mer- } \\
\text { chandise } \\
\text { export in } \\
2006 \text { ) }\end{array}$} & \multicolumn{2}{|l|}{$\begin{array}{l}\text { Technological } \\
\text { capability }\end{array}$} & \multicolumn{2}{|c|}{ GDP growth rate } \\
\hline & & & $\begin{array}{l}\text { Net export } \\
\text { ratio of } \\
\text { complex } \\
\text { manufactured } \\
\text { goods in } 2014\end{array}$ & $\begin{array}{l}\text { Improvement } \\
\text { of net } \\
\text { export ratio } \\
\text { between } \\
1995 \text { and } \\
2014\end{array}$ & $\begin{array}{l}\text { Annual } \\
\text { average for } \\
2003-2014\end{array}$ & $\begin{array}{l}\text { Percentage } \\
\text { points } \\
\text { difference } \\
\text { between } \\
2003-08 \\
\text { and } \\
2009-14\end{array}$ \\
\hline Poland & 3.3 & 10.7 & -0.04 & 0.42 & 3.9 & -2.0 \\
\hline Singapore & 1.7 & 14.6 & -0.18 & 0.55 & 6.1 & -1.5 \\
\hline Turkey & 5.4 & 8.0 & -0.33 & 0.43 & 4.8 & -2.1 \\
\hline Indonesia & 5.8 & 43.6 & -0.36 & 0.25 & 5.6 & 0.0 \\
\hline $\begin{array}{l}\text { South } \\
\text { Africa }\end{array}$ & 2.5 & 39.7 & -0.37 & 0.00 & 3.1 & -2.7 \\
\hline Argentina & 2.8 & 21.0 & -0.5 & 0.08 & 5.7 & -4.1 \\
\hline Colombia & 2.2 & 46.8 & -0.9 & 0.00 & 4.7 & -0.9 \\
\hline Pakistan & 1.3 & 6.8 & n.a. & n.a. & 4.4 & -2.1 \\
\hline
\end{tabular}

Sources Market size, Natural resource export, and GDP growth rate come from own calculation based on data derived from World Development Indicator database and IMF's Economic Outlook database; Net export ratio comes from own calculation based on data derived from RIETI's Trade Industry Database 2014. http://www.rieti-tid.com/. Accessed 25 November 2016

industries of wine, salmon, wood, and fruit, but their spillover effect in the domestic economy is low.

(2) The large domestic market countries can be divided into two groups. China, South Korea, and India succeeded in improving their NERs substantially between 1995 and 2014, and China and South Korea came to have positive NERs by 2014. Brazil, Russia, and Mexico, in contrast, experienced either a decline or zero improvement in NERs between 1995 and 2014; furthermore, their NERs in 2014 were either negative or zero. To grow economically in the global market, the former three countries are making efforts to improve the technological capability of their industries without solely depending on their large-market advantage. The latter group is weak in the area of technological upgrading.

(3) The countries in the third group have small domestic markets (except for the relatively large markets of Turkey and Indonesia). Their dependence on resource exportation is also much smaller than the first-group countries. What is char- 
acteristic of the third-group countries is the substantial improvement of their technological capability. All the countries except for South Africa and two Latin American countries (Argentina and Colombia) improved their NERs to a great extent between the years of 1995 and 2014, suggesting that their success largely depended on upgrading their technological capability which helped deepen their participation in the GPNs. It should also be noted that the expansion of regional (intra-Asian) trade and investment in the manufacturing industries has helped the Asian emerging states to form regional division-of-labor networks in which they upgraded their respective industrial structure and stepped up the value chains jointly, a pathway which is limited to a minimum in Latin America and Africa.

In conclusion, low levels of institutional globalization have not imposed insurmountable constraints on emerging states' ability to more deeply participate in economic globalization and to benefit from it in terms of achieving high rates of economic growth. This is because they have certain advantage factors such as large domestic markets, abundant natural resources for export, and appropriate technological capabilities that are attractive to global traders/investors regardless of the degree of institutional globalization of each emerging state. Every emerging state has at least one of the three advantage factors. All of these results demonstrate that the alarmist view does not fit the experience of emerging states as far as economic growth is concerned. However, endorsing the optimistic view is premature because economies that are excessively dependent on exporting natural resources are vulnerable to volatility in the international prices of commodities. It is also not easy for emerging states to compete with each other to keep up with the speed of technological upgrading demanded by the GPNs. I will return to this subject in Sect. 2.6, which deals with the future prospects of the emerging states.

\subsubsection{Social Policy and Income Distribution}

One of the most serious concerns about globalization is its presumed negative impact on national policymaking autonomy and the resultant deterioration of social welfare and protection. Unfortunately, it is more difficult to obtain social data (as opposed to economic data) that is comparable across many countries. In addition, different countries use different definitions of social welfare and protection. Here, I am compelled to look only at Asia and Latin America and to rely on separate datasets for each region.

Tables 2.3 and 2.4 show the share (in GDP) of public spending on social insurance and assistance (or welfare) in six Latin American countries and nine Asian countries respectively. In all five Latin American countries with data available for the period of 1991-2002, the annual average share of social spending improved between the first period (1991-1994) and the second (1999-2002). The nineteen-nineties was the decade in which these countries implemented reforms oriented toward institutional 
Table 2.3 Public expenditures for social insurance and social assistance (share of GDP, annual average)

\begin{tabular}{l|l|l|l}
\hline & $1991-94$ & $1999-2002$ & $2009-2012$ \\
\hline Argentina & 8.4 & 8.5 & 10.4 \\
\hline Brazil & 9.6 & 11.3 & 12.8 \\
\hline Chile & 7.2 & 7.5 & 6.6 \\
\hline Colombia & 2.6 & 4.4 & 7.7 \\
\hline Mexico & 0.4 & 2.2 & 3.1 \\
\hline Peru & n.a. & 4.1 & 3.3 \\
\hline
\end{tabular}

Source CEPAL (2016)

Table 2.4 Central government expenditure for social insurance and welfare (share of GDP, annual average)

\begin{tabular}{l|l|l|l}
\hline & $1991-95$ & $2000-2004$ & $2010-2014$ \\
\hline China & 0.2 & 1.2 & 2.4 \\
\hline India & n.a. & 0.8 & $0.5(2010-13)$ \\
\hline South Korea & 1.1 & 2.9 & 4.8 \\
\hline Taiwan & 3.4 & 4.0 & 3.4 \\
\hline Malaysia & 0.9 & 1.2 & 1.0 \\
\hline Thailand & 0.5 & 1.6 & 1.9 \\
\hline Philippines & 0.3 & 0.8 & 1.2 \\
\hline Indonesia & $0.9(1994-95)$ & $1.3(2001-04)$ & n.a. \\
\hline Singapore & $0.8(1995)$ & $0.6(2000)$ & $1.5(2011-14)$ \\
\hline
\end{tabular}

Note GDP of all the countries except for India is for calendar year. Government expenditure is also for calendar year for all the countries except for Taiwan (up to 2000), Thailand, and Singapore. Government expenditure of these countries and India is for fiscal year. Definition of "social insurance and welfare" differs from one country to another. Source ADB $(2010,2016)$

globalization, such as fiscal balance, privatization, trade and investment liberalization, and increased flexibility within the labor market in exchange for debt relief arranged by the IMF and the US government. As a result of these reforms, labor conditions generally deteriorated, although the degree of deterioration diverged according to the power and structure of labor unions (Teichman 2001; Murillo 2001). Contradicting the alarmist view, Table 2.3 shows that Latin American governments responded to social dislocations during a period of rapid globalization by increasing the share (if not the absolute amount) of social spending.

Table 2.4 indicates that the pattern of change in social spending in Asia is similar to that of Latin America between the first period (1991-1995) and the second (2000-2004), although the GDP share of social spending was much smaller in Asia. The social welfare system in the Asian countries has been described as "productive welfare capitalism" (Holliday 2000; Kim 2016), the "developmental welfare state" (Kwon 2002), or the "Listian workfare national state" (Jessop 2016). These authors share the view that people's welfare was secured not so much by the welfare state 
as by the increase in employment opportunities that the government helped create by fostering labor-intensive industries and by enhancing educational opportunities. Social policy was thus subordinate to economic policy. Even so, Asian governments needed to increase social spending to cope with the social dislocations caused by the AFC and post-AFC market reforms (institutional globalization). The countries that experienced a democratic transition between the late 1980s and the late 1990s (such as South Korea, the Philippines, Thailand, Taiwan, and Indonesia) were also exposed to greater pressure from their electorates to increase social provisions for healthcare, pensions, and social assistance. ${ }^{8}$ Singapore provides a notably exceptional case that substantiates the alarmist view that globalization brings deterioration of social welfare. Singapore is the most globalized of the emerging countries, scoring highest on the Economic Freedom Score and trade and FDI ratios to GDP among the emerging states; differing from other Asian countries, it responded to the AFC by reducing social spending. It also reduced firms' obligatory contributions to the Central Provident Fund (the national fund composed of individual accounts that are used for healthcare, pensions, and other individual expenses) (Kim 2016, pp. 113-14).

During the following decade, four Latin American countries and five Asian countries (including Singapore) increased their share of GDP dedicated to social spending. Chile, Peru, India, Taiwan, and Malaysia are in the minority of countries that reduced their social spending share. Together, Tables 2.3 and 2.4 show that the emerging states in Asia and Latin America could generally expand their social spending in the face of social dislocations caused by economic crises and greater exposure to globalization. However, whether such fiscal expansion contributed to a decline in social disparity is a separate question.

Figures 2.6 and 2.7 provide information on changes in income distribution in Latin America and Asia during the period of 1989-2013. Fig 2.6 reveals a seeming contradiction concerning the effect of social spending in Latin America. In three of the seven Latin American countries (Argentina, Colombia, and Venezuela), income distribution deteriorated between the first period (1989-1991) and the third period (2001-2003). In addition, Mexico experienced a slight deterioration in income distribution between the first period (1989-1991) and the second period (1995-1997). A similar deterioration was observed in Peru from the second period (1995-1997) to the third (2001-2003). As we saw above, these were the periods during which the share of social spending increased in those countries.

In contrast, after the period of 2001-2003, income distribution improved in all the countries, including Chile and Peru that reduced their share of GDP devoted to social spending.

One explanation for this seeming contradiction between changes in social spending and changes in income distribution in Latin America is the enormous social dislocations that the debt crisis and hyperinflation (of a magnitude of three to four

\footnotetext{
${ }^{8}$ Both Ramesh (2003) and Kim (2016) stress the importance of electoral competition in the expansion of welfare programs in South Korea and Taiwan. The universal health care program introduced in 2001 by Thaksin Sinawatra, then prime minister of Thailand, is another example of electoral-populist policy.
} 


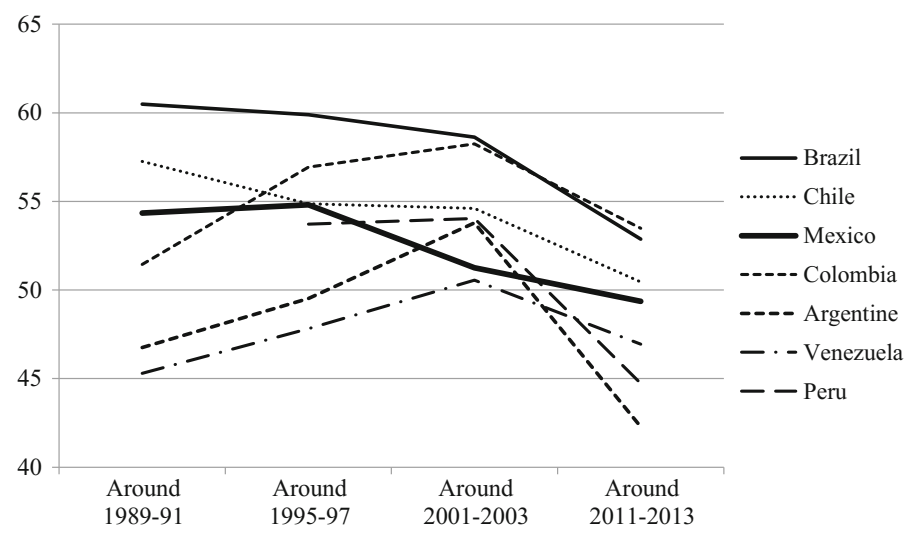

Fig. 2.6 GINI index in Latin American countries (distribution of income). Source World Bank's PovcalNet database. http://iresearch.worldbank.org/PovcalNet/povOnDemand.aspx. Accessed 3 December 2016

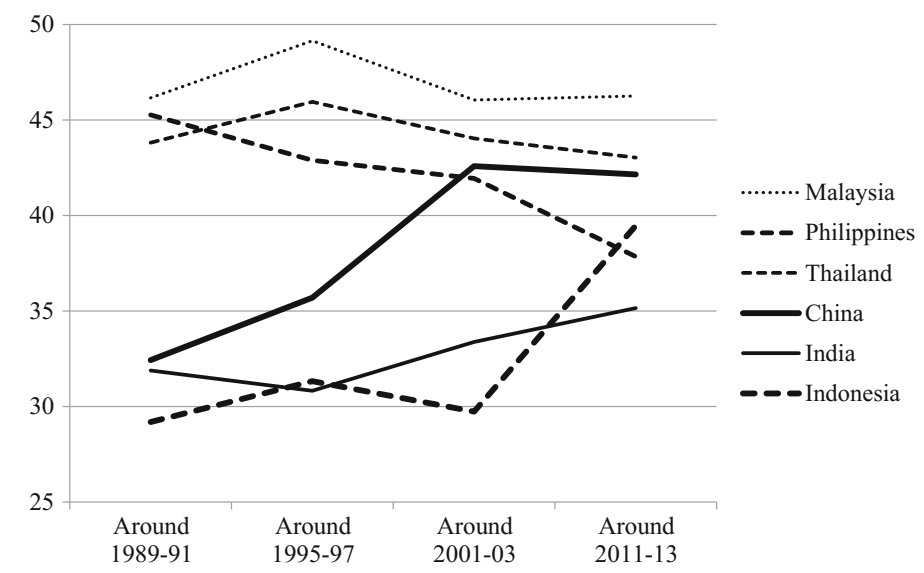

Fig. 2.7 GINI index in Asian countries (distribution of income or consumption expenditure). Note Figure for Malaysia is distribution of income. All others are distribution of consumption expenditure. Source World Bank's PovcalNet database. http://iresearch.worldbank.org/PovcalNet/ povOnDemand.aspx. Accessed 3 December 2016

digits) incurred in the region during the 1980s and the first half of the 1990s. Such social dislocations were so serious that even a substantial increase in social spending during the 1990s could not compensate for the damages. Social spending started to have some effects only in the 2000s when economic conditions were normalized. In addition, many Latin American countries introduced conditional cash transfer (CCT) programs during the 2000s. As these programs attempted to focus on the poorest segments of the population, they may have contributed to the improvement of income distribution. As of 2010, the number of beneficiaries of these programs 
reached 29\% (Argentina), 27\% (Brazil), 25\% (Colombia), and 24\% (Mexico) of the country's total populations (Stampini and Tornarolli 2012, p. 10).

The important role of social spending notwithstanding, many studies on income distribution in Latin America point out that a large part of the improvement in income distribution during the 2000s is explained by economic growth rather than by income redistribution. For instance, Stampini and Tornarolli (2012, p. 12) indicate that it was economic growth that contributed to reducing the number of poor households. The reduction was so rapid that CCT became less redistributive as families whose income had been improved continued to receive the benefits. A World Bank study team found that a rapid and sizable increase in upward mobility, from the low-income to the middle-income strata, occurred after 2003 and that $74 \%$ of the increase in the number of middle-income families (those with \$10-50 USD of income per day) can be explained by the increase in per capita income. The rest is attributable to income redistribution (Ferreira et al. 2013, pp. 3-4). Birdsall (2014, p. 264) reached the same conclusion concerning Brazil. Also discussing Brazil, Power (2016, p. 214) attributed $54.9 \%$ of the disparity shrinkage to the improvement in labor remuneration and only $12.2 \%$ to Bolsa Familia (Brazil's CCT program).

The pattern of change in income distribution in Asia is quite different from that in Latin America. As shown in Fig. 2.7, the increase in the social spending share of GDP is generally more closely associated with the improvement of income distribution in Asia. Between the second period (1995-1997) and the third (2001-2003), Malaysia, Thailand, and Indonesia, which were most heavily hit by the AFC, ${ }^{9}$ enhanced their social spending and also saw an improvement in income distribution. After 2003, Malaysia and India reduced their share of GDP devoted to social spending, and their income distribution deteriorated, while China, Thailand, and the Philippines experienced both increased social spending and improvement in income distribution.

Furthermore, high economic growths in the Asian countries contributed to general improvement of poor people's life. However, different from the Latin American pattern, high growth rates did not necessarily guarantee a reduction in income disparity in Asia, as shown by the experiences of India and China between the second period (1995-1997) and the third (2001-2003), and the experiences of India, Malaysia, and Indonesia between the third period (2001-2003) and the fourth (2011-2013). In these countries, the growth of globally integrated sectors and regions has been so speedy that other sectors and regions are left behind.

In conclusion, as in the case of economic growth, neither the alarmist nor the optimistic view of globalization could explain the pattern of social spending and income distribution in Asia and Latin America. Most of the emerging states in Asia and Latin America expanded social-spending shares to cope with shocks caused by economic crises and subsequent market reforms promoting institutional globalization. ${ }^{10}$

\footnotetext{
${ }^{9}$ South Korea is another victim of the AFC but is not mentioned here due to the absence of comparable data.

${ }^{10}$ A study by a World Bank group demonstrated that poverty-oriented universal health care programs enhanced coverage between 2006 and 2011 not only in Asia and Latin American but also in countries such as Nigeria, South Africa, and Turkey (Cotlear et al. 2015, Table 1.1).
} 
Economic globalization helped the Asian and Latin American countries attain high rates of economic growth, which in turn contributed to reducing income disparity. However, contradicting the optimistic view, there are cases in which social spending was not enough to compensate for the social dislocations caused by economic shocks and institutional globalization or by regionally and sectorally imbalanced growth. Neither is steady economic growth (that will contribute to reducing income disparity) guaranteed. As discussed in the previous subsection, continuous economic growth largely depends on the future availability of the advantage factors that each emerging state can offer.

\subsubsection{Globalization and Political Transformation}

As Rodrik's trilemma argument indicates, the pessimist view of globalization insists that it is incompatible with democracy while the more cautious view endorsed by Acemoglu and Robinson admits the possibility that globalization facilitates democratization under certain conditions.

Many of the works dealing with democratization in the post-Cold War era indicate that the post-Cold War euphoria of "third wave" democratization (Huntington 1991) receded by the early 2000s; Larry Diamond observed that "the trend toward democracy has been accompanied by an even more dramatic trend toward pseudodemocracy" (Diamond 2002, p. 27). Authors use slightly different definitions of "pseudodemocracy," but they share the view that, in contrast to outright autocracy, pseudodemocratic (or hybrid, competitive authoritarian, or electoral authoritarian) regimes adopt many conventional democratic institutions, especially multi-party elections. In many cases, semi-authoritarian regimes manage these institutions in ways that are highly disadvantageous to the opposition, although elections can work against authoritarian continuity under certain conditions (Brownlee 2007; Levitsky and Way 2010; Schedler 2013). These observations indicate that neither the transition to democracy nor to autocracy has been a dominant pattern during the period of hyper-globalization.

Table 2.5, which categorizes emerging states by their regime types during the periods of 1991-1993 and 2013-2015, substantiate this contention. Twenty-one out of the twenty-eight emerging states $(72 \%)$ had the same kind of political regime during the 2013-2015 period that they had during the 1991-1993 period, while the remaining eight states shifted from "partly free" regimes to "free" or "not free" regimes in equal number (four for each). There was no general tendency toward authoritarian resurgence or toward democratic transition as far as the emerging states were concerned. This observation supports the cautious view that the political-regime impact of globalization is not monotonic.

Table 2.5 also shows that the relative degree of globalization is not associated with specific regime or regime change. "I" in the parentheses indicate that the score of institutional globalization of that country was higher than the median of the scores of all 28 emerging states. "E" means relatively high economic globalization (trade 
Table 2.5 Political regime in 1991-1993 and 2013-2015

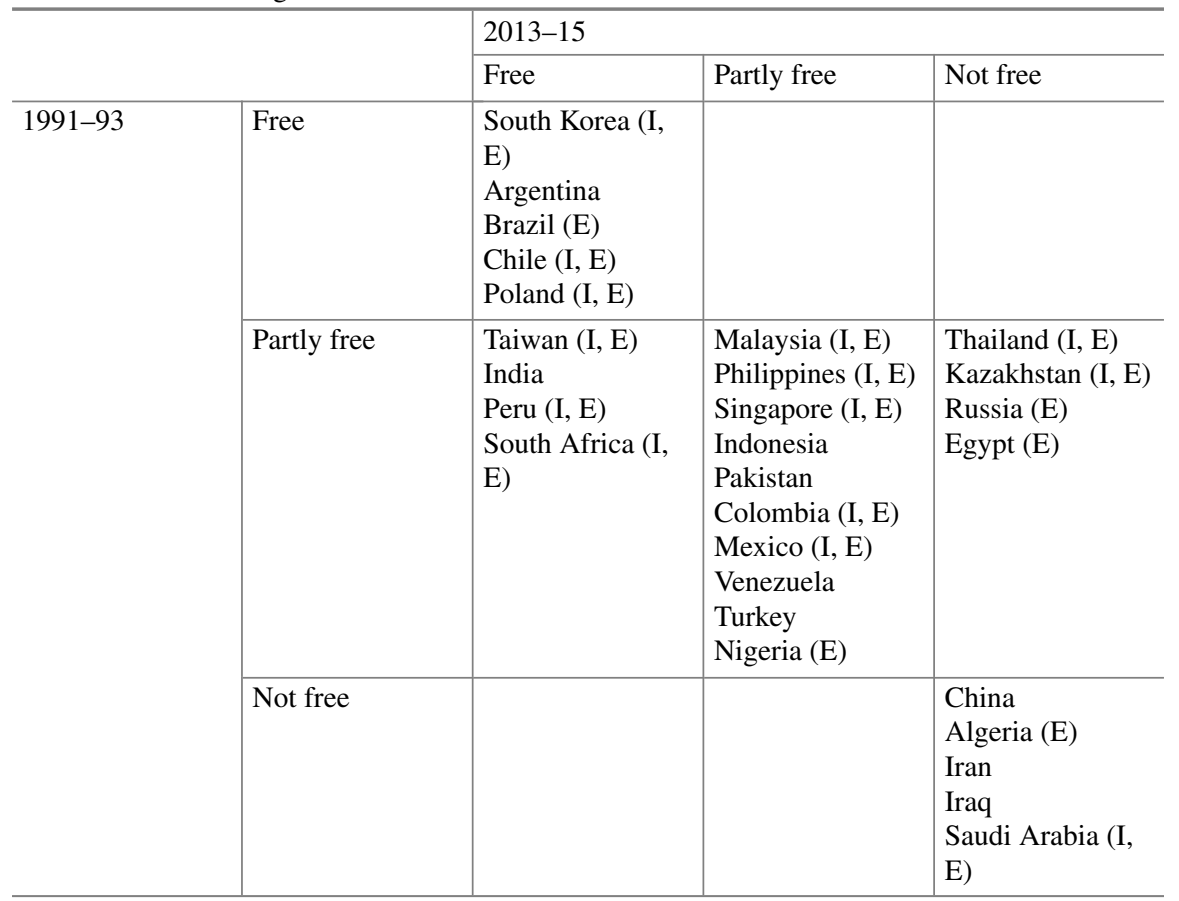

Source Freedom House "Freedom in the World Country Ratings," accessed 11 August 2015; Appendix 2

share and/or FDI share). The countries which were "not free" in both 1991-1993 and 2013-2015 tend to record relatively low institutional and economic globalization. Beside this tendency, Table 2.5 demonstrates that the relatively high globalization does not necessarily favors specific political regime or regime transformation.

\subsection{Institutions and Economic and Social Performance}

The above examination of economic, social, and political impacts of globalization shows that the cautious view best grasps what has actually happened in the emerging states. Globalization does not always foster or impede economic growth. It depends on the nature of advantage factors that each emerging state can offer to the global economy. Neither does globalization always bring the enhancement or shrinkage of social equity. It depends on deepness of economic crises, sustainability of economic growth, and the degree of imbalanced development in different localities and sectors. Finally, globalization does not necessarily foster democracy or autocracy. The cautious view of globalization, as I discussed in Sect. 2.3.1, emphasizes the impor- 
tance of political and institutional arrangements to explain the differing economic performance of national states. This is because sustained economic growth in the context of globalization requires the coordination of interests among big (foreign and domestic) firms, small producers, and workers in order to deepen and broaden domestic linkages for technological upgrading. The similar interest coordination will be needed to cope with the major concern of the alarmist view of globalization- the loss of social cohesion due to the enhancing gap between globally integrated and benefited segments of the population and those who are left behind with little connection to globalized networks and benefits. To alleviate this social disparity, tradable sectors and higher income people must bear the tax burden generated by redistributive measures.

The questions are best stated as follows: Under which political order (or institutional complex) can this type of coordination be optimally achieved, and how can such order be formed and maintained politically? Many studies seem to indicate that successful coordination depends on a political order in which the state is not easily subject to pressure from special interest groups or rent-seeking individuals but at the same time is close enough to the private sector for consultation and cooperation. For instance, Doner et al. (2005, p. 328) argue that to successfully cope with coordination and other problems relating to upgrading, a country needs "organizational complexes in which experts and coherent bureaucratic agencies collaborate with organized private sectors to spur national economic transformation." In this regard, South Korea, Taiwan, and Singapore are superior to Malaysia, Thailand, Indonesia, and the Philippines. This argument is an extension of earlier work on "embedded autonomy" (Evans 1995) and "governed interdependence" (Weiss and Hobson 1995; Weiss 1998). Coinciding with Macintyre (2003), who examined the divergent responses of Southeast Asian countries to the AFC, Doner believes that under the optimal institutional arrangement, the number of veto players (i.e., influential actors in policymaking) is neither too large nor too small. Having too many veto players facilitates free-riding and consequently makes consensus-building difficult. Too small a number of veto players will heighten the fear of arbitrary policy changes and therefore lower the credibility of lasting commitment by top political leaders. Neither is good for the coordination of those involved in technological upgrading (Doner 2009, pp. 92-93).

\subsubsection{Political Regime as a Macro-Political Institution}

To examine the coordinating functions of different political and institutional arrangements, I first focus on political regime as a macro-political institution. The number of veto players is usually smaller in the authoritarian regimes than in the democratic regime. However, we can generally expect that the optimal political order in which veto players are neither too many nor too few are found most frequently in regimes that fall between the democratic and the authoritarian ends of the political order spectrum. In Table 2.5, "partly free" regimes are such intermediate regimes. 
Table 2.6 Political regime and improvement in income distribution

\begin{tabular}{|c|c|c|c|c|}
\hline & & \multicolumn{3}{|l|}{ 2001-03 } \\
\hline & & Free & Partly free & Not free \\
\hline \multirow[t]{3}{*}{ 1989-91 } & Free & $\begin{array}{l}\text { Brazil } \\
\text { Chile } \\
\text { India } \\
\text { Thailand }\end{array}$ & $\begin{array}{l}\text { Argentina } \\
\text { Venezuela }\end{array}$ & \\
\hline & Partly free & $\begin{array}{l}\text { Mexico } \\
\text { Peru } \\
\text { Philippines }\end{array}$ & $\begin{array}{l}\text { Colombia } \\
\text { Indonesia } \\
\text { Malaysia }\end{array}$ & \\
\hline & Not free & & & China \\
\hline & & \multicolumn{3}{|l|}{ 2011-13 } \\
\hline & & Free & Partly free & Not free \\
\hline \multirow[t]{3}{*}{$2001-03$} & Free & $\begin{array}{l}\text { Brazil } \\
\text { Chile } \\
\text { India } \\
\text { Peru }\end{array}$ & $\begin{array}{l}\text { Mexico } \\
\text { Philippines } \\
\text { Thailand }\end{array}$ & \\
\hline & Partly free & $\begin{array}{l}\text { Argentina } \\
\text { Indonesia }\end{array}$ & $\begin{array}{l}\text { Colombia } \\
\text { Malaysia } \\
\text { Venezuela }\end{array}$ & \\
\hline & Not free & & & China \\
\hline
\end{tabular}

Note The countries in bold letters are those that recorded the improvement of income distribution. Sources Freedom House "Freedom in the World Country Ratings" (accessed 11 August 2015) and Figs. 2.6 and 2.7 in this chapter

It is true that the largest number of the emerging states is concentrated in the category in which the regimes were "partly free" in both 1991-1993 and 2013-2015. However, If the numbers of the emerging states that had either democratic or authoritarian regimes in the two periods are counted together, they are as numerous as the consistently "partly free" countries. In addition, the equal number of countries changed their regime from "partly free" to "free" or "not free" between 1991-1993 and 2013-2015. The nature of political regime does not seem to be associated with the economic performance of the emerging states.

As for social performance, since we have only limited data on income distribution, it is difficult to find clear patterns. In Table 2.6, the names of the countries that saw significant improvement in income distribution appear in bold. During the periods of 1989-1991 and 2001-2003, the countries that remained "free" or became freer (Brazil, Chile, Mexico, and the Philippines) showed improvement in social performance. However, such a tendency ceased to be observed after the period of 2001-2003, in which most of the "free" and "partly free" countries equally experienced social improvement.

In short, we cannot conclude that semi-authoritarian regimes have achieved superior economic and social performances. We must investigate institutional variations among countries with the same regime types. For instance, writing from a historical point of view, Slater (2010) compared the "ordering power" of Southeast Asian states. 
He argued that their ordering power diverges because different relations between the state and the elites developed due to divergent experiences of class and/or communal conflict during the early post-colonial era. In countries such as Malaysia and Singapore, elites (state officials, economic elites, middle class, communal leaders) needed protection from the state in the face of endemic and unmanageable internal threats. As a result, a strong and durable regime capable of extracting resources even from its elite members as the need arose was formed. In contrast, the state leaders of the Philippines, Thailand, and South Vietnam needed to provide wasteful patronage benefits to secure the support of the elites, as these elites did not face serious mass mobilization and were fragmented among themselves. Consequently, the political regime in the latter group of countries became fragile both politically and economically. From a more functional point of view, Macintyre (2003) attempts to explain divergent veto-player distributions by examining factors such as the number of political parties, their internal cohesiveness, and executive-legislative relations. Rock (2013) distinguishes majoritarian institutions from proportional institutions. Even concerning the highly authoritarian China, Breznitz and Murphree (2011, Chap. 1) use the term "structural uncertainty" to indicate the institutional complexity that leaves reform policies ambiguous; this allows multiple interpretations that accommodate various policy players in the central government, local governments, and the Communist Party.

\subsubsection{Bureaucracy as a Micro-Level Institution}

Examining the variations in micro-level institutions in the emerging states is a necessary but daunting task. In this chapter, I will only examine the nature of the state bureaucracy. This is because almost all literature concerning the role of the state in development regards the insulation of the governing body from special social interests as an essential element of good performance. "Embeddedness" with market and society is another important element for success. However, it is difficult to measure the degree of "embeddedness." In contrast, Evans and Rauch (1999) provide unique and useful data on "Weberianness" of the economic bureaucracy. They measure the nature of the bureaucracy by their organizational features. They especially emphasize two factors: meritocratic recruitment and promotion and a predictable career ladder which provides long-term tangible and intangible rewards. These structural features will contribute to the development of competent, purposive, and cohesive bureaucracy with a long-term perspective. It is expected that such bureaucracy will be less susceptible to the private capture and value public purposes.

Evans and Rauch (1999) provide "Weberianness scale scores" for 35 developing countries, out of which 18 are the emerging states. Table 2.7 shows the nature of political regime and "Weberianness" of the bureaucracy in these countries in the late 1990s. The figures in parentheses indicate the growth rate between 1990 and 2014 adopted from Appendix 1. The sample is too small to have any conclusive observation, but "Weberianness" seems to explain differential growth rates better 
Table 2.7 Political regime, Weberianness of bureaucracy, and economic growth

\begin{tabular}{l|l|l|l|l}
\hline \multicolumn{2}{l}{} & \multicolumn{3}{|l}{ Weberianness of bureaucracy (late 1990s) } \\
\cline { 3 - 5 } \multicolumn{2}{c|}{} & High & Medium & Low \\
\hline $\begin{array}{l}\text { Political regime } \\
\text { (1998-2000) }\end{array}$ & Free & $\begin{array}{l}\text { India (352) } \\
\text { South Korea } \\
(227)\end{array}$ & & $\begin{array}{l}\text { Argentina (129) } \\
\text { Chile (221) } \\
\text { Philippines (165) } \\
\text { Taiwan (231) }\end{array}$ \\
\cline { 2 - 5 } & Partly free & $\begin{array}{l}\text { Malaysia (284) } \\
\text { Singapore (316) }\end{array}$ & $\begin{array}{l}\text { Brazil (103) } \\
\text { Colombia (135) } \\
\text { Mexico (90) } \\
\text { Thailand (170) } \\
\text { Turkey (149) }\end{array}$ & $\begin{array}{l}\text { Nigeria (245) } \\
\text { Peru (209) }\end{array}$ \\
\cline { 2 - 5 } & Not free & Pakistan (158) & Egypt (165) & \\
\hline
\end{tabular}

Note When the Weberian scale score of a country exceeds ten, the country is categorized as a "high" Weberianness state while it is categorized as a "low" Weberianness state when the score is smaller than six. Sources Weberianness of bureaucracy is from Evans and Rauch (1999), Appendix C; Political regime is from Freedom House database

than the nature of political regimes. The emerging states with high "Weberianness" recorded higher growth rates than the countries with medium or low "Weberianness" except for Pakistan and Nigeria. Pakistan is "high" in terms of Weberian structure of its bureaucracy but economic performance is low. Nigeria recorded a high economic growth in spite of low Weberianness of its bureaucracy. However, it should be recalled that Nigeria, together with Chile and Peru in Table 2.7, is a country highly dependent of natural resource exports. Economic growth of resource-rich countries may not need a professional bureaucracy as long as the international price of resources is high.

Beside the nature of bureaucracy, we can think of many other micro- or meso-level institutions that may affect the capability of individual national states to respond to opportunities and risks of globalization. Mechanisms linking the public and private sectors, relationship between the executive and legislative branches of a government, and the electoral and party system are some of such institutions. The examination of these institutions, however, cannot be taken up in this study. Such attempt must await another research opportunity.

\subsection{Future of the Emerging States}

\subsubsection{Modes of Global Integration}

As discussed in Sect. 2.4.1, emerging states have achieved strong economic performances by participating in and benefiting from economic globalization. To do so, they offered various advantage factors to global actors, such as natural resources, 
large domestic markets, and appropriate technological capabilities. The question to be asked is whether emerging states will be able to maintain or improve their current rate of catching-up by relying on their current advantage factors.

The exportation of natural resources seems to be the least promising path. For one thing, excessive dependence on the exportation of natural resources is risky and unsustainable, as the international price of natural resources is notoriously unstable. One way out of this impasse involves building and strengthening downstream processing industries. The oil palm industry and the rubber industry in Malaysia, and the food processing industries in Thailand, are successful cases in this respect (Rasiah 2006; Oikawa 2015; Kawano 2017; Suehiro 2017; Intarakumnerd 2017). However, as the case of Chile shows, the development of resource processing industries may face limitations unless the benefits of their development spill over into more technologically advanced sectors.

Countries like China and India are at an advantage based on the mere size of their domestic markets. To gain access to such large markets, global economic players will continue to cajole these countries into the economic globalization process regardless of their poor record of institutional globalization. However, it should be noted that not all large-market countries have a high growth rate. For instance, China and Brazil share a similar FDI-to-GDP ratio (Fig. 2.5), but the growth rates of these two countries are spectacularly different. Table 2.2 clearly indicates that high-growth large-market countries (China, India, and South Korea) have made far greater efforts in upgrading the technological capability of their industries. In contrast, the technological capabilities of Brazil, Russia, and Mexico deteriorated or showed no improvement between 1995 and 2014. Schneider (2013, pp. 170-71) wrote that Brazilian private firms (with the exception of certain natural resource companies) have low levels of funding for their R\&D activities despite various promotional policies of the government. In contrast, according to Sihna (2016), who analyzed the pharmaceutical and textile industries in India, the private sector of that country, confronted with pressing WTO obligations, changed its strategy from sheltering under government protection to seeking to promote exports and international competitiveness. As a consequence, these industries increased their R\&D expenditures and extended backward and forward linkages of production. On the other hand, in their analysis of the electronics and ICT industries in China, Breznitz and Murphree (2011, p.3) point out that "China can excel in a wide array of innovative activities that might not advance the technological frontier but can certainly transform how the global economy works."

The countries that have neither a large domestic market nor an abundant resource endowment will need to be continuously integrated into the GPNs as exporters of manufactured goods and providers of business support services. Although there are cases in which technological "catch-down" (or downgrade) for specific domestic markets results in greater value capture (Coe and Yeung 2015, p. 173), it will be indispensable in the long run for emerging states to upgrade their technological capability if they want to maintain or improve their status in the GPN. As Yusuf (2004, p. 6) pointedly argues, these countries' competitiveness is "predicated on technological deepening" (also see Paus 2012, p. 117; Chandra and Kolavalli 2006, p. 19). 
In the final analysis, all types of emerging states will be required to pay greater attention to the improvement of the technological capabilities of their firms and labor forces. For this purpose, close interest coordination must be fulfilled among big firms, upstream and downstream firms, and labor force.

On the other hand, the analysis in Sect. 2.4.2 shows that greater global integration and resultant economic growth have not necessarily brought social equity and cohesion. Although economic growth itself helps improve income distribution in many cases, the role of the public sector continues to be important in ensuring the social welfare of the general population. As with technological upgrading, such welfare policies require political coordination of the distribution of burdens and benefits among domestic players.

\subsubsection{Coordination Capability for Technological Upgrading and Inclusive Growth}

As discussed in Sect. 2.5, many scholarly works agree that governing institutions' strong coordination capabilities frequently stem from their "embedded autonomy." They must have an internal cohesiveness and institutional capacity that can help ward off capture by particularistic interests and prioritize long-term national goals. At the same time, they must maintain close cooperative and consultative relations with social and economic actors to effectively monitor the market and social situations and secure the adoption and implementation of optimal policies. There are several factors we need to consider in our assessment of the prospects of each emerging state to maintain, strengthen, or build such capabilities anew.

First, some scholars say that private local firms have been enhancing their influence vis-à-vis state institutions. As early as 1995, Evans warned that domestic firms were strengthening their ties with MNCs while distancing themselves from the state; as a result, the "embedded autonomy" of the state may be undermined. Twenty years later, Yeung (2016) argued that economic success no longer depended on national states but on the development of GPNs based on close connections among private firms that extend beyond national borders. If any role remains for the government, it will be primarily to assist national-global articulation by helping domestic firms seek out specialized niches within the global economy. If this is the dominant tendency in the contemporary world, much of the work of coordinating interests to promote technological upgrading and inclusive growth will have to be left primarily in the hands of domestic private firms and their global allies. Room for coordination from a national point of view will be narrowed unless the private sector itself has a mechanism that can broadly coordinate the interests of big firms (both domestic and multinational), smaller suppliers and other domestic firms, workers, and people left out of the economic globalization process.

Second, the implications of the growing middle-class conservatism for "embedded autonomy" must be considered. Many authors point out an amazing expansion 
of the middle class in the emerging states (ADB 2010; Chen 2013; Ferreira et al. 2013; Power 2016). At the same time, several authors observe that this middle class is increasingly conservative in political terms. For instance, Kurlantzick (2013) contends that middle-class people feel threatened by the post-Cold War trend of democratization because democracy usually empowers the poor more than the middle class and endangers the middle class's economic, political, and social privileges. As a consequence, members of the middle class support authoritarian leaders in many countries, including Thailand, Venezuela, Russia, and China. Writing on the military coup of 2014 and its aftermath in Thailand, Kanchoochat (2016) observes that many professionals supported the coup and participated in the post-coup government. Reid (2014, Chap. 13) discerns increasing dissatisfaction among members of the Brazilian middle class and their participation in street demonstrations against the elected left-wing government. Middle-class conservatism does not necessarily mean a decline in the coordination capabilities of public institutions. As middle-class people's prosperity largely depends on continuing economic growth, they may support efforts to promote national technological upgrading. However, if their conservatism deters them from serving as a counterbalance against powerful private enterprises, it may end up dampening the effort to broaden and deepen domestic linkages to build technological capabilities and foster income redistribution.

Third, the mobilization of low-income people can impact the capability of public institutions. As the economies of the emerging states grew quickly, income levels even at the bottom of the economic ladder increased, raising people's expectations for an even better material life. Such expectations may put pressure on political leaders to enhance redistributive measures, thereby jeopardizing growth-oriented activities by strengthening the middle-class conservatism mentioned above and potentially frightening away private investors. Impediments to economic activities will become even more serious if political leaders attempt to mobilize the masses using populist rhetoric and practices. Reid (2014) mentioned the economic and political upheaval during the second half of the Labor Party's administration in Brazil, while Güven (2016) argued that the increasingly populist policies of the AKP government have impeded the structural transformation of the Turkish economy. The confusion and stagnation caused by the Thaksin administration and the subsequent coup is another well-known example of a populist debacle. In such a situation, we cannot expect public institutions to achieve effective interest coordination pertinent to technological upgrading and equitable growth.

Fourth, historical legacies that take the form of institutional path-dependence and ideational persistency may constrain the coordination capabilities of emerging states. As I mentioned in Sect. 2.4.3, Slater (2010) differentiated the "ordering power" of Southeast Asian states and attributed the divergence to each country's historical experiences of domestic crises threatening their elites. Doner et al. (2005) argued that institutional complexes that promote technological upgrading developed in South Korea, Taiwan, and Singapore to a greater extent than in other Southeast Asian countries. This difference originates from different historical experiences of internal and external crises. On the other hand, authors such as Bruce Gilley and Elizabeth Thurbon emphasize the importance of the ideational influence of the past. Gilley (2014) 
contends that the concept of the "virtuous ruler" persists throughout Asian history. This notion is supported by a shared culture that prioritizes the state-run by virtuous political leaders committed to the common good and constrained by the social norms of accountability - as the key entity guaranteeing national integrity, people's wellbeing, political stability, and economic development. Writing about contemporary South Korea, Thurbon (2016) echoes Gilley by saying that the "developmental mindset" persists not only among politicians and state officials but also in the population at large, and that this mindset helped bring about the resurgence of once-weakened public financing for high-tech industries. Institutional and ideational legacies may reinforce the coordination capabilities of public institutions. They may, however, jeopardize such capabilities if state elites behave in a self-righteous or predatory way without paying proper attention to the economic and social conditions of the nation.

Last but not least, political leadership may make a difference. Where a nation's historical legacies support strong public institutions, top leaders' policy choices will affect the degree to which the legacies are effectively utilized to strengthen the nation's coordination capabilities. Where historical legacies are not quite appropriate for the embedded-autonomy mode of interest coordination, leaders can still try to introduce institutions that limit the number of veto players in order to facilitate interest coordination. Furthermore, institutions that facilitate coordination will be more resilient if they are endorsed by a range of social and economic forces that support the broadening and deepening of domestic linkages. ${ }^{11}$ To do so, political elites need to build a firm and stable coalition of these forces while resisting the temptation of populist mobilization or the comfort of the conservative status quo.

\subsection{Concluding Remarks}

Somewhat ironically, we are currently witnessing strong antagonism toward globalization in some "advanced" industrial countries more so than in emerging states. The latter have successfully skirted the constraints of institutional globalization and have taken advantage of economic globalization in order to catch up with the advanced countries. Provided that the current anti-globalization mood in some advanced countries does not turn into long-term protectionist policies that spread across the world, some of the upper-middle-income emerging states will attain a high-income status, and some small but rapidly growing countries will achieve the status of emerging states in the years to come.

In order to productively integrate into the economic globalization process and benefit from it, emerging states have attracted global investors/traders by providing advantage factors such as large domestic markets, abundant natural resources, appropriate technological capabilities, or a combination thereof. In the final analysis, however, upgrading the technological capabilities of domestic firms and the

\footnotetext{
${ }^{11}$ Teichman (2016, p. 25) argues that a broad, cross-class consensus will help bolster the state's capacity and political will to pursue inclusive development.
} 
domestic labor force, along with strengthening domestic production linkages, will be crucial for the emerging states to advance further. They will also need to enhance redistributive measures and reinforce social linkages by narrowing the gap between the globally integrated populations and regions and those that have been left behind. Otherwise, anti-globalism, as witnessed in some advanced countries, may also flare up in the emerging states.

Strengthening both kinds of linkages requires a strong commitment to coordination among economic and social forces such as large enterprises, local suppliers, workers, the middle class, and disadvantaged people. In this sense, it is a political rather than an economic and/or technical endeavor, and, consequently, public institutions must be involved.

As for the future of the emerging states, this chapter presented five factors that can affect their coordination capability. These were identified as firm-government relations ("embedded autonomy"), middle-class conservatism, populist mobilization, institutional and ideational legacies of the past, and political leadership. Related to historical legacies and political leadership, institutional arrangements that promote a higher level of coordination capability must be explored. This chapter indicates that macro-institutions such as political regimes are not associated with the economic and social performance of emerging states, and therefore it focused on the bureaucracy as an example of micro-level institutions. The bureaucracy is certainly among the most important micro-level institutions that affect the coordination capability of national states. However, deeper and broader examination of the bureaucracy and other institutions is needed as it is beyond the scope of this chapter.

This chapter concludes by contending that the five factors mentioned above will undoubtedly affect the future trajectories of emerging states; as such, they should certainly be counted as major themes in emerging state studies.

\section{Appendix 1: GDP Growth Rate and GDP Per Capita}

\begin{tabular}{l|l|l|l}
\hline & $\begin{array}{l}\text { GDP growth rate } \\
\text { between } 1990 \text { and } \\
2014\end{array}$ & $\begin{array}{l}\text { GDP as percent of US } \\
\text { GDP in 2014 }\end{array}$ & $\begin{array}{l}\text { GDP per capita at } \\
\text { current US\$ in 2014 }\end{array}$ \\
\hline \multicolumn{4}{l}{ High-income countries } \\
\hline Singapore & 316 & 1.7 & 56,007 \\
\hline Taiwan & 231 & 3.1 & 22,626 \\
\hline South Korea & 227 & 7.6 & 27,989 \\
\hline Chile & 221 & 1.6 & 14,566 \\
\hline Saudi Arabia & 165 & 4.0 & 24,406 \\
\hline Poland & 136 & 3.3 & 14,337
\end{tabular}

(continued) 
(continued)

\begin{tabular}{|c|c|c|c|}
\hline & $\begin{array}{l}\text { GDP growth rate } \\
\text { between } 1990 \text { and } \\
2014\end{array}$ & $\begin{array}{l}\text { GDP as percent of US } \\
\text { GDP in } 2014\end{array}$ & $\begin{array}{l}\text { GDP per capita at } \\
\text { current US\$ in } 2014\end{array}$ \\
\hline Russia & 19 & 10.4 & 13,902 \\
\hline \multicolumn{4}{|c|}{ Upper middle income countries } \\
\hline China & 899 & 50.9 & 7587 \\
\hline Malaysia & 284 & 1.9 & 11,307 \\
\hline Peru & 209 & 1.1 & 6549 \\
\hline Thailand & 170 & 2.4 & 5970 \\
\hline Turkey & 149 & 5.4 & 10,304 \\
\hline Iraq & 148 & 1.1 & 6336 \\
\hline Colombia & 135 & 2.2 & 7918 \\
\hline Argentina & 129 & 2.8 & 12,325 \\
\hline Iran & 126 & 2.9 & 5443 \\
\hline Brazil & 103 & 14.9 & 11,729 \\
\hline Algeria & 99 & 1.1 & 5484 \\
\hline Mexico & 90 & 7.3 & 10,351 \\
\hline Kazakhstan & 90 & 1.1 & 13,155 \\
\hline South Africa & 84 & 2.5 & 6472 \\
\hline Venezuela & 79 & 2.6 & 12,265 \\
\hline \multicolumn{4}{|c|}{ Lower middle income countries } \\
\hline India & 352 & 13.6 & 1577 \\
\hline Nigeria & 245 & 2.8 & 3203 \\
\hline Indonesia & 214 & 5.8 & 3500 \\
\hline Egypt & 165 & 1.5 & 3366 \\
\hline Philippines & 165 & 1.6 & 2873 \\
\hline Pakistan & 158 & 1.3 & 1315 \\
\hline United States & 78 & 100.0 & 54,398 \\
\hline
\end{tabular}

Note Income group classification is according to the definition (based on GNI per capita) by the World Bank. Sources Own calculation based on data from World Development Indicator database and ADB $(2000,2016)$. The GDP data used for the calculation of growth rates and ratios to US GDP are at constant 2010 US \$ for all the countries except Taiwan. For Taiwan, figures at current price are used due to the data limitation 


\section{Appendix 2: Institutional and Economic Globalization and GDP Growth Rate (Annual Average)}

\begin{tabular}{|c|c|c|c|c|c|c|}
\hline & Institutional & Economic g & obalization & & & GDP \\
\hline & & $\begin{array}{l}\text { Ratio of } \\
\text { trade to } \\
\text { GDP, } \\
\text { average for } \\
2003-14\end{array}$ & $\begin{array}{l}\text { Ratio of } \\
\text { inward FDI } \\
\text { to GDP, } \\
\text { average for } \\
2003-15\end{array}$ & $\begin{array}{l}\text { Share of } \\
\text { trade in } \\
\text { world total } \\
\text { trade, } \\
2003-14\end{array}$ & $\begin{array}{l}\text { Share of } \\
\text { inward FDI } \\
\text { in world } \\
\text { total FDI, } \\
2003-15\end{array}$ & \\
\hline Algeria & 54.5 & 68 & 1.2 & 0.25 & 0.13 & 3.6 \\
\hline Argentina & 51.5 & 36 & 2.1 & 0.36 & 0.56 & 5.7 \\
\hline Brazil & 58.5 & 26 & 2.5 & 1.14 & 3.43 & 3.5 \\
\hline Chile & 77.8 & 70 & 7.1 & 0.35 & 1.02 & 4.2 \\
\hline China & 52.4 & 54 & 2.2 & 10.94 & 7.22 & 10.0 \\
\hline Colombia & 64.3 & 37 & 3.9 & 0.27 & 0.74 & 4.7 \\
\hline Egypt & 56.2 & 53 & 3.7 & 0.26 & 0.41 & 4.3 \\
\hline India & 53.8 & 47 & 1.8 & 2.35 & 1.85 & 7.6 \\
\hline Indonesia & 54.6 & 53 & 1.6 & 0.83 & 0.80 & 5.6 \\
\hline Iran & 43.9 & 49 & 0.9 & 0.33 & 0.22 & 3.4 \\
\hline Kazakhstan & 59.2 & 82 & 7.4 & 0.24 & 0.69 & 6.8 \\
\hline $\begin{array}{l}\text { South } \\
\text { Korea }\end{array}$ & 68.8 & 89 & 1.0 & 2.91 & 0.77 & 3.7 \\
\hline Malaysia & 64.2 & 174 & 3.2 & 0.97 & 0.55 & 5.2 \\
\hline Mexico & 66.2 & 59 & 2.5 & 2.03 & 1.94 & 2.5 \\
\hline Nigeria & 53.4 & 53 & 2.8 & 0.32 & 0.43 & 8.7 \\
\hline Peru & 65.2 & 49 & 4.4 & 0.21 & 0.46 & 5.9 \\
\hline Philippines & 57.3 & 79 & 1.3 & 0.39 & 0.17 & 5.4 \\
\hline Poland & 61.9 & 81 & 2.8 & 1.11 & 0.86 & 3.9 \\
\hline Russia & 51.2 & 52 & 2.5 & 1.65 & 2.59 & 4.1 \\
\hline $\begin{array}{l}\text { Saudi } \\
\text { Arabia }\end{array}$ & 62.7 & 84 & 3.6 & 1.13 & 1.30 & 6.0 \\
\hline Singapore & 87.8 & 390 & 19.0 & 2.33 & 2.96 & 6.1 \\
\hline $\begin{array}{l}\text { South } \\
\text { Africa }\end{array}$ & 63.6 & 59 & 1.5 & 0.48 & 0.36 & 3.1 \\
\hline Taiwan & 70.9 & 126 & 0.7 & 1.52 & 0.23 & 4.2 \\
\hline Thailand & 63.8 & 131 & 3.2 & 1.23 & 0.67 & 4.0 \\
\hline
\end{tabular}


(continued)

\begin{tabular}{|c|c|c|c|c|c|c|}
\hline & \multirow{2}{*}{$\begin{array}{l}\text { Institutional } \\
\text { globaliza- } \\
\text { tion } \\
\text { (Economic } \\
\text { freedom } \\
\text { score, } \\
2003-2014 \text { ) }\end{array}$} & \multicolumn{4}{|c|}{ Economic globalization } & \multirow{2}{*}{$\begin{array}{l}\text { GDP } \\
\text { growth rate } \\
(2003-14)\end{array}$} \\
\hline & & $\begin{array}{l}\text { Ratio of } \\
\text { trade to } \\
\text { GDP, } \\
\text { average for } \\
2003-14\end{array}$ & $\begin{array}{l}\text { Ratio of } \\
\text { inward FDI } \\
\text { to GDP, } \\
\text { average for } \\
2003-15\end{array}$ & $\begin{array}{l}\text { Share of } \\
\text { trade in } \\
\text { world total } \\
\text { trade, } \\
2003-14\end{array}$ & $\begin{array}{l}\text { Share of } \\
\text { inward FDI } \\
\text { in world } \\
\text { total FDI, } \\
2003-15\end{array}$ & \\
\hline Turkey & 59.1 & 52 & 1.9 & 1.03 & 0.92 & 4.8 \\
\hline Venezuela & 42.4 & 52 & 1.1 & 0.22 & 0.17 & 3.9 \\
\hline
\end{tabular}

Sources Economic Freedom Score is from own calculation based on Heritage Foundation's economic freedom scores (http://www.heritage.org/index, accessed on 21 November 2016); Ratio of trade to GDP is from own calculation based on data derived from World Development Indicator database and ADB (2016); Ratio of inward FDI, Share of trade in world total trade, and Share of inward FDI in world total FDI are from own calculation based on data derived from UNCTADSTAT database (http://unctadstat.unctad.org/wds/ReportFolders/ reportFolders.aspx?sCS_ChosenLang=en, accessed on 27 November 2016); GDP growth rate is from own calculation based on data derived from World Development Indicator database, ADB (2016), and IMF's Economic Outlook database

\section{References}

Aaron, F., Chani, E., \& Mishra, S. (2013). How to avoid middle income traps? Evidence from Malaysia. Policy Research Working Paper No. 6427. Washington, D.C.: The World Bank.

Acemoglu, D., \& Robinson, J. A. (2006). Economic origins of dictatorship and democracy. New York: Cambridge University Press.

Asian Development Bank (ADB). (2000). Key indicators for Asia and the Pacific 2000. Manila: ADB.

Asian Development Bank (ADB). (2010). Key indicators for Asia and the Pacific 2010. Manila: ADB.

Asian Development Bank (ADB). (2016). Key indicators for Asia and the Pacific 2016. Manila: ADB.

Birdsall, N. (2014). A note on the middle class in Latin America. In R. Kanbur, C. Rhee, \& J. Zhuang (Eds.), Inequality in Asia and the Pacific: Trends, drivers, and policy implications (pp. 257-287). Manila: ADB, UK: Routledge.

Breznitz, D., \& Murphree, M. (2011). Run of the red queen: Government, innovation, globalization, and economic growth in China. New Haven and London: Yale University Press.

Brownlee, J. (2007). Authoritarianism in an age of democratization. Cambridge: Cambridge University Press.

Caldentey, E. P. (2012). Income convergence, capability divergence, and the middle income trap: An analysis of the case of Chile. Studies in Comparative International Development, 47, 185-207.

Chandra, V., \& Kolavalli, S. (Eds.). (2006). Technology, adaptation, and exports: How some developing countries got it right. Washington, D.C.: The World Bank. 
Chen, J. (2013). A middle class without democracy: Economic growth and the prospects for democratization in China. Oxford and New York: Oxford University Press.

Coe, N. M., \& Yeung, H. W. (2015). Global production networks: Theorizing economic development in an interconnected world. Oxford: Oxford University Press.

Comisión Económica para América Latina y el Caribe (CEPAL). (2016). Panorama Social de América Latina 2015. Santiago: CEPAL.

Cotlear, D., Nagpal, S., Smith, O., Tandon, A., \& Cortez, R. (2015). Going universal: How 24 developing countries are implementing universal health coverage reforms from the bottom up. Washington, D.C.: International Bank for Reconstruction and Development/The World Bank.

Diamond, L. (2002). Thinking about hybrid regimes. Journal of Democracy, 13(2), 21-35.

Doner, R. F. (2009). The politics of uneven development: Thailand's economic growth in comparative perspective. Cambridge: Cambridge University Press.

Doner, R. F. (2015). Success as trap? Crises and challenges in export-oriented Southeast Asia. In T. J. Pempel \& K. Tsunekawa (Eds.), Two crises, different outcomes: East Asia and global finance (pp. 163-184). Ithaca and London: Cornell University Press.

Doner, R. F., \& Ramsay, A. (2003). The challenges of economic upgrading in liberalizing Thailand. In L. Weiss (Ed.), States in the global economy: Bringing domestic institutions back in (pp. 121-141). Cambridge: Cambridge University Press.

Doner, R. F., Ritchie, B. K., \& Slater, D. (2005). Systemic vulnerability and the origins of developmental states: Northeast and Southeast Asia in comparative perspective. International Organization, 59, 327-361.

Doner, R. F., \& Schneider, B. R. (2016). The middle-income trap: More politics than economics. World Politics, 68(4), 608-644.

Evans, P. (1995). Embedded autonomy: States and industrial transformation. Princeton: Princeton University Press.

Evans, P., \& Rauch, J. E. (1999). Bureaucracy and growth: A cross-national analysis of the effects of 'Weberian' state structures on economic growth. American Sociological Review, 64(5), 748-765.

Felipe, J., Abdon, A., \& Kumar, U. (2012). Tracking the middle-income trap: What is it, who is in it, and why? Levy Economics Institute of Bard College Working Paper No 715.

Ferreira, F. H. G., Messina, J., Rigolini, J., López-Calva, L., Lugo, M. A., \& Vakis, R. (2013). Economic mobility and the rise of the Latin American middle class. Washington, D.C.: The World Bank.

Friedman, T. L. (1999/2000). The lexus and the olive tree: Understanding globalization (Updated and Expanded ed.). New York: Farrar Straus Giroux.

Gill, I., \& Kharas, H. (2007). An East Asian renaissance: Ideas for economic growth. Washington, D.C.: The World Bank.

Gill, I., \& Kharas, H. (2015). The middle-income trap turns ten. World Bank Policy Research Working Paper No. 7403.

Gilley, B. (2014). The nature of Asian politics. New York: Cambridge University Press.

Güven, A. B. (2016). The political economy of Turkish democracy. In C. Erisen \& P. Kubicek (Eds.), Democratic consolidation in Turkey: Micro and macro challenges (pp. 184-203). London and New York: Routledge.

Holliday, I. (2000). Productivist welfare capitalism: Social policy in East Asia. Political Studies, 48(4), 706-723.

Huntington, S. P. (1991). The third wave: Democratization in the late twentieth century. Norman: University of Oklahoma Press.

Intarakumnerd, P. (2017). Industrial innovation in Thailand: The electronics, automotive and seafood sectors. In B. T. Khoo \& K. Tsunekawa (Eds.), South East Asia beyond traps and crises: Economic growth and upgrading (pp. 167-192). London: Palgrave Macmillan.

Jessop, B. (2016). The developmental state in an era of finance-dominated accumulation. In Y.-W. Chu (Ed.), The Asian developmental state: Reexaminations and new departures (pp. 27-55). Basingstoke, UK: Palgrave Macmillan. 
Kanchoochat, V. (2016). Reign-seeking and rise of the unelected in Thailand. Journal of Contemporary Asia, 46(3), 486-503.

Kaplan, S. B. (2013). Globalization and austerity politics in Latin America. Cambridge: Cambridge University Press.

Kawano, M. (2017). Upgrading Malaysia's rubber manufacturing: Trajectories and challenges. In B. T. Khoo \& K. Tsunekawa (Eds.), South East Asia beyond traps and crises: Economic growth and upgrading (pp. 193-223). London: Palgrave Macmillan.

Kim, M. M. S. (2016). Comparative welfare capitalism in East Asia: Productivist models of social policy. New York: Palgrave Macmillan.

Kohli, H. S., Sharma, A., \& Sood, A. (Eds.). (2011). Asia 2050: Realizing the Asian century. Los Angeles, London, New Delhi, Singapore, and Washington, DC: Sage Publications.

Kurlantzick, J. (2013). Democracy in retreat: The revolt of the middle class and the worldwide decline of representative government. New Haven \& London: Yale University Press.

Kwon, H.-J. (2002). Welfare reform and future challenges in the Republic of Korea: Beyond the developmental welfare state? International Social Security Review, 55(4), 23-38.

Levitsky, S., \& Way, L. A. (2010). Competitive authoritarianism: Hybrid regimes after the cold war. Cambridge: Cambridge University Press.

MacIntyre, A. (2003). The power of institutions: Political architecture and governance. Ithaca and London: Cornell University Press.

Maddison, A. (1995). Monitoring the world economy 1820-1992. Paris: OECD.

Mosley, L. (2003). Global capital and national governments. Cambridge: Cambridge University Press.

Murillo, M. V. (2001). Labor unions, partisan coalitions, and market reform in Latin America. Cambridge and New York: Cambridge University Press.

Ohmae, K. (1990). The borderless world: Power and strategy in the interlinked economy. Harper Business.

Ohmae, K. (1996). The end of the nation state: The rise of regional economies. New York: Simon \& Schuster Inc.

Ohno, K. (2009). Avoiding the middle-income trap: Renovating industrial policy formulation in Vietnam. ASEAN Economic Bulletin, 26(1), 25-43.

Oikawa, H. (2015). Mareshia pamuyu sangyo no hatten to shigen riyogata kyacchiappu kogyoka [Development of Malaysian palm oil industry and resource-based catching-up industrialization]. Ajia Keizai [Asian Economy], 56(2), 41-71.

Paus, E. (2012). Confronting the middle income trap: Insights from small latecomers. Studies in Comparative International Development, 47(2), 115-138.

Polanyi, K. (2001). The great transformation: The political and economic origins of our time. Second Beacon Paperback edition. First published 1944.

Power, T. J. (2016). The reduction of poverty and inequality in Brazil: Political causes, political consequences. In B. R. Schneider (Ed.), New order and progress: Development and democracy in Brazil (pp. 212-237). New York: Oxford University Press.

Ramesh, M. (2003). Globalization and social security expansion in East Asia. In L. Weiss (Ed.), States in the global economy: Bringing domestic institutions back in (pp. 83-98). Cambridge: Cambridge University Press.

Rasiah, R. (2006). Explaining Malaysia's export expansion in palm oil and related products. In V. Chandra (Ed.), Technology, adaptation, and exports: How some developing countries got it right (pp. 163-192). Washington, D.C.: The World Bank.

Reid, M. (2014). Brazil: The troubled rise of a global power. New Haven and London: Yale University Press.

Rock, M. T. (2013). East Asia's democratic developmental states and economic growth. Journal of East Asian Studies, 13, 1-34.

Rodrik, D. (1997). Has globalization gone too far?. Washington, D.C.: Institute for International Economics. 
Rodrik, D. (2007). One economics, many recipes: Globalization, institutions, and economic growth. Princeton and London: Princeton University Press.

Rodrik, D. (2011). The globalization paradox: Why global markets, states, and democracy can't coexist. Oxford: Oxford University Press.

Schedler, A. (2013). The politics of uncertainty: Sustaining and subverting electoral authoritarianism. Oxford: Oxford University Press.

Schneider, B. R. (2013). Hierarchical capitalism in Latin America: Business, labor, and the challenges of equitable development. New York: Cambridge University Press.

Sihna, A. (2016). Globalizing India: How global rules and markets are shaping india's rise to power. Cambridge: Cambridge University Press.

Slater, D. (2010). Ordering power: Contentious politics and authoritarian leviathans in Southeast Asia. Cambridge: Cambridge University Press.

Stampini, M., \& Tornarolli, L. (2012). The growth of conditional cash transfers in Latin America and the Caribbean: Did they go too far? Social Sector, Social Protection and Health Division (Inter-American Development Bank) Policy Brief No. 185.

Strange, S. (1996). The retreat of the state: The diffusion of power in the world economy. Cambridge: Cambridge University Press.

Suehiro, A. (2017). New growth strategies of Thailand's big firms in the ASEAN economic community era. In B. T. Khoo \& K. Tsunekawa (Eds.), South East Asia beyond traps and crises: Economic growth and upgrading (pp. 35-69). UK: Palgrave Macmillan.

Teichman, J. A. (2001). The politics of freeing markets in Latin America: Chile, Argentina and Mexico. Chapel Hill and London: The University of North Carolina Press.

Teichman, J. A. (2016). The politics of inclusive development: Policy, state capacity, and coalition building. Basingstoke and New York: Palgrave Macmillan.

Thurbon, E. (2016). Developmental mindset: The revival of financial activism in South Korea. Ithaca and London: Cornell University Press.

Weiss, L. (1998). The myth of the powerless state: Governing the economy in a global era. Cambridge: Polity Press.

Weiss, L., \& Hobson, J. M. (1995). States and economic development: A comparative historical analysis. UK: Policy Press.

Wibbels, E. (2006). Dependency revisited: International markets, business cycles, and social spending in the developing world. International Organization, 60, 433-468 (Spring).

World Bank. (2000). World development report 2000/2001: Attacking poverty. Washington, D.C.: The World Bank.

Yeung, H. W. (2016). Strategic coupling: East Asian industrial transformation in the new global economy. Ithaca and London: Cornell University Press.

Yusuf, S. (2004). Competitiveness through technological advances under global production networking. In S. Yusuf, M. A. Altaf, \& K. Nabeshima (Eds.), Global production networking and technological change in East Asia (pp. 1-34). Washington, DC: The World Bank.

Yusuf, S., \& Nabeshima, K. (2009). Tiger economies under threat: A comparative analysis of Malaysia's industrial prospects and policy options. Washington DC: World Bank. 
Open Access This chapter is licensed under the terms of the Creative Commons AttributionNonCommercial-NoDerivatives 4.0 International License (http://creativecommons.org/licenses/bync-nd/4.0/), which permits any noncommercial use, sharing, distribution and reproduction in any medium or format, as long as you give appropriate credit to the original author(s) and the source, provide a link to the Creative Commons license and indicate if you modified the licensed material. You do not have permission under this license to share adapted material derived from this chapter or parts of it.

The images or other third party material in this chapter are included in the chapter's Creative Commons license, unless indicated otherwise in a credit line to the material. If material is not included in the chapter's Creative Commons license and your intended use is not permitted by statutory regulation or exceeds the permitted use, you will need to obtain permission directly from the copyright holder.

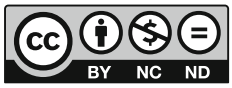

